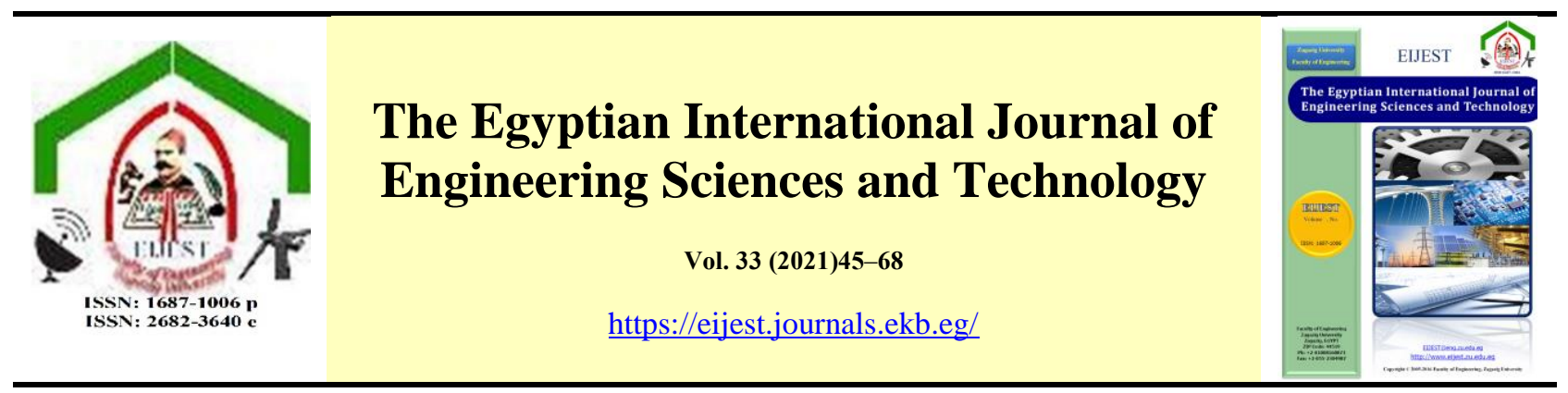

\title{
Orientation-Optimization Simulation for Solar Photovoltaic Plant of Cairo International Airport
}

\author{
Mohamed S. Emeara, Ahmed F. AbdelGawad, Ahmed El Abgay* \\ Mechanical Power Engineering Dept., Faculty of Engineering, Zagazig University, Zagazig 44519, Egypt

A B S T R A C T

\begin{tabular}{l}
\hline A R T I C L E I N F O \\
\hline Keywords: \\
Photovoltaic Plant \\
Cairo International Airport \\
Orientation Optimization \\
Energy Simulation \\
PVsyst
\end{tabular}

Solar energy is a prompt creating source of energy worldwide. Airports are typically large, shade-free structures and have great areas, which offer the idealistic platform for installing large surfaces of photovoltaic panels generating more than $20 \mathrm{GW} / \mathrm{yr}$. Optimization of the photovoltaic system is a main factor to promote the power conversion efficiency. Solar-radiation amount depends on an essential factor, which is the orientation of the photovoltaic modules. The azimuth and tilt angles for the photovoltaic panels are important factors that impact the receiving of the solar radiation, accordingly have a major influence on the photovoltaic system performance. PVsyst software is an important simulation software for the design of the photovoltaic system. Also, PVsyst enables the calculation of the amount of energy generated. This study provides a proposal for installing a photovoltaic plant in Cairo International Airport. Moreover, the study gives several orientation cases to get the optimal yearly tilt and azimuth angles. The optimal tilt and azimuth angles should be obtained to enhance the annual energy yield. The study also improves the energy generation by carrying out optimization to obtain the dualseasonal optimal tilt angles for summer and winter. The simulation for the energy generation and the orientation-optimization analysis was done by the PVsyst software. The optimization results indicated that the optimal azimuth angle is $0^{\circ}$, the optimal yearly tilt angle is $30^{\circ}$, and the generated energy is around $35 \mathrm{GWh} / \mathrm{yr}$. The optimal dual-seasonal tilt angles are $10^{\circ}$ in summer and $50^{\circ}$ in winter that maximized the generated energy to be about $36.5 \mathrm{GWh} / \mathrm{yr}$. This optimization study contributes effectively to increase the energy production by installing a photovoltaic plant and using an optimal photovoltaic panel-orientation, as well as being able to save about $50 \%$ of Cairo-International-Airport Terminal-Building 3 yearly electrical consumption.

\section{Introduction}

\subsection{Renewable Solar Energy}

Economic extension of countries is moved by their sources of energy. Globalization and industrialization have directed to consumption of nonrenewable energy sources. Currently all countries are seeking for alternate sources of energy, among of them, the solar energy is the most numerously exist form of renewable energy [1], [2]. Compared with other systems reliant upon renewable energy whether it is wind, geothermal, or biomass energy, photovoltaic systems are becoming more widespread [3], [4]. Solar PV power is represented to be a common renewable energy source in the industrial and residential sectors. The cause is because of its outstanding characteristics such as abundance

* Corresponding author. Tel.: +02-01007950627

E-mail address: ahmed.elabagy@gmail.com. 
availability, zero cost of fuel, less cost of maintenance, non-existence of rotating parts, applicability for installation in various places, and no pollution [5]. PV energy is a promising source of clean energy [6]. It is sustainable and it is able to be transformed directly into electricity using PV panels [2]. Solar PV became the world's speediest-mounting renewable energy technology as per a cosmopolitan electricity market in 2018 [7]. Photovoltaic represent a significant function in decreasing global warming and achieving climate change objectives [1]. The significant side here is that electrical energy acquired from the sun require to be conserved to be used during off-sunshine hours. As well, solar energy has numerous else implementation such as it is able to be applied on solar pump, room heating, water heating, etc. [1].

\subsection{Airport PV Plant}

The aviation industry is a main contributor at greenhouse gases emission. The growing in focus on greenhouse gases is the major reason of global warming and climate change [8]. The electricity request in airport buildings is principally achieved out of electricity produced from traditional energy sources that cause pollution. Airports electricity is consumed principally from air conditioning, buildings lighting and airfield, and electromechanical installations. A major concern for airports to promote tools in order to minimize the energy consumption. Doing this through achievement energy saving ways and by enhancing renewable energy usage [9]. The installation of solar photovoltaic close to the airport represents a very effective in reducing airport ground emissions. The amount of power that can be produced by solar relies on the available area. Land area needed for Megawatt scale solar plant should be great, shade-free also low cost regardless of solar radiation [8]. Airports are usually great, isolated, shade free structures which offering the idealistic platform for installing or planning to install large surfaces of PV panels producing more than $20 \mathrm{GW}$ [10], [8], [11].

Sukumarana, and Sudhakar (2017) presented a proposal study for the installation of an onsite solar photovoltaic power plant for Raja Bhoj International Airport. The simulation study demonstrated that the plant was able of producing 2,733 $\mathrm{MWh} / \mathrm{yr}$ of electrical energy [8].

Recent years many airports have implemented PV plants on their available great areas in order to meet their electricity demand. Here are some excellent examples of such Airport PV Plants:

- The Saarbrücken Airport in Germany

The first solar power plant in the Megawatt class in the Saarland region of Germany has been connected to the power grid, with a capacity of 3.6 megawatts. The power plant area is about 40,000 square meter, it has been built on fallow ground in the airport area [4].

- Aichi Airport in Japan

A bifacial PV fence-type was vertically installed. The bifacial photovoltaic installed on the outer fence of the global loop in the EXPO 2005 Aichi, Japan. The whole production system was moved into the site close to the Aichi Airport [12].

- Kuala Lumpur International Airport (KLIA) in Malaysia

The largest Malaysian airport that uses renewable energy for covering its energy demands. The plant saved approximately 2.1 million RM $(\$ 627,000)$ annually and produced around 19 gigawatt hour in 2018 and decreased the emitted carbon dioxide by 6742 tons yearly [9].

- Cochin International Airport in India

The prosperous achievement of photovoltaic in airports has made Cochin airport the first fully solar powered in the world. The airport generates solar energy of 30 megawatts to meet energy demand. Surplus energy is supplied to the near electrical grid, as shown in Figure 1 [9].

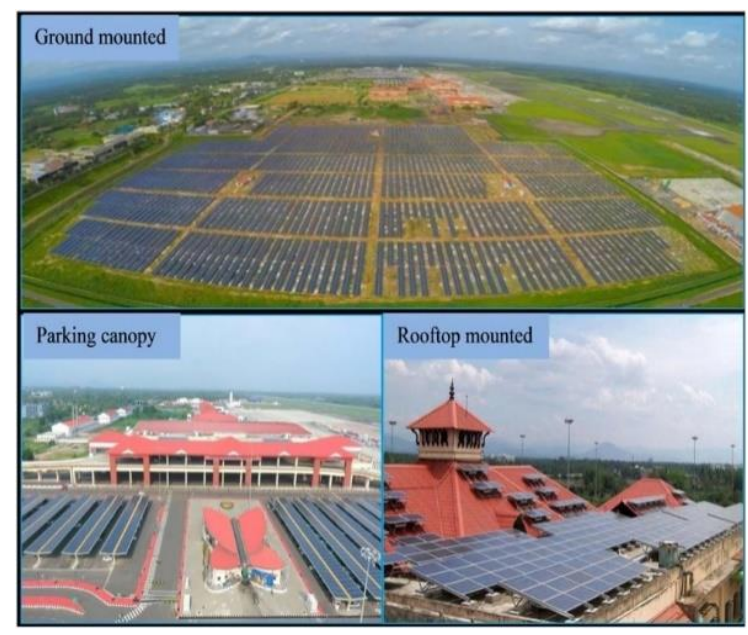

Fig. 1: PV Plant on International Airport in India [9]

\subsection{PV Solar Energy Optimization}

Applying renewable energy results to abundant 
features inclosing decrease of power conveyance cost and reduction of the global warming issues. The optimization of the solar energy system is the key factor to promote the power transformation efficiency [7]. The growing interest in using optimization technologies to spread solar PV systems worldwide is developing from research published [7].

The earth receives daily a great influx of solar energy. The power of this radiation relies on sundry standards, meteorological conditions, and atmospheric spread [13]. PV system depends highly on the layout design (e.g., size, type, location, and orientation of the panels) [6]. One of the important challenges compared to a conventional energy source is its lower transformation efficiency and power change because of variation in photovoltaic cell temperature, ambient temperature, the solar irradiation, azimuth, angle and the tilt angle. Accordingly, there is an important possibility to extract more solar energy to improve the capacity utilization factor with the already existing infrastructure [5].

\subsection{PVsyst Software}

PVsyst is an important simulation tool designed first in Geneva and gives an analysis of PV systems [1]. PVsyst is one of the best simulation software to evaluate the performance of a solar PV power plant [14]. Pvsyst gives a help in the system configuration design as well as enables calculating the produced energy. Its simulation result is dependent on the PV panels sizing, which based principally on the geographical PV project location [1].

\section{Research Methodology}

\subsection{PV Plant Case Study}

After displaying the proposal PV plant study in Raja Bhoj International Airport, presenting various PV plants that were implemented in many airports around the world (which highlighted the effective feedback of generating partly or fully the requirement of the airport's energy such as Cochin International Airport), and by reviewing the areas available at Cairo International Airport through the Google Earth, it was found that an area suitable for a PV plant can be identified in the south of Terminal Building No. 3 .

In this paper, we provide a proposal analysis for the PV plant installation at Cairo International
Airport. The proposed PV-plant area is $800 \times 600 \mathrm{~m}^{2}$ (About $500,000 \mathrm{~m}^{2}$ ). The PV cells area is $100,000 \mathrm{~m}^{2}$ with rows of $650 \mathrm{PV}$ stands (each stand holds $5 \mathrm{PV}$ panels $) \times 15$ columns $(48,750$ units of PV panel $410 \mathrm{~W}$ ). Figure 2 shows the schematic of the PV plant [2] where $\mathrm{W}=650 \mathrm{~m}, \mathrm{~L}=450 \mathrm{~m}, \mathrm{M}=650$ panels, $\mathrm{N}=15$ rows, $\mathrm{H}=1 \mathrm{~m}$, and $\mathrm{V}=10.25 \mathrm{~m}$.

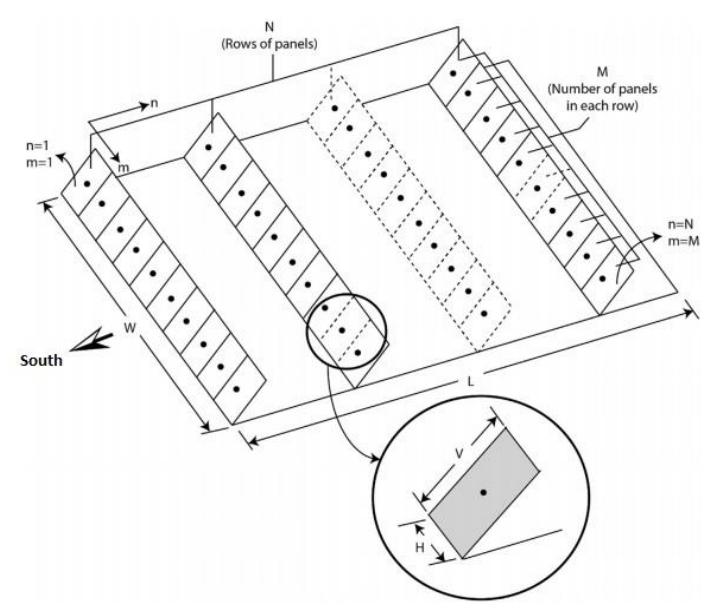

Fig. 2: schematic of the PV plant [2]

\subsection{PV Optimization}

The existence of solar radiation is a significant and substantial factor for the proper functioning of the solar energy system. The energy generated by solar PV differs with the variation in solar irradiation through the day. The precision of the solar energy system is basically affected by the weather parameters. Therefore, optimization plays an imperious role in enhancing the thoroughness and effectiveness of the solar system [7].

\subsubsection{Azimuth and Tilt Angles}

The orientation of azimuth and tilt angles of PV panels is an essential input for PV performance studies [15]. The orientation of azimuth and tilt angles plays a significant role in promoting the generation efficiency of the PV panels. The generation efficiency is mainly influenced by the amount of solar radiation incidence on PV panels. Solar-radiation magnitude depends on two important factors, azimuth and tilt angles of panels [16], [17], [3], [18]. Figure 3 illustrates azimuth and tilt angles [19]. 


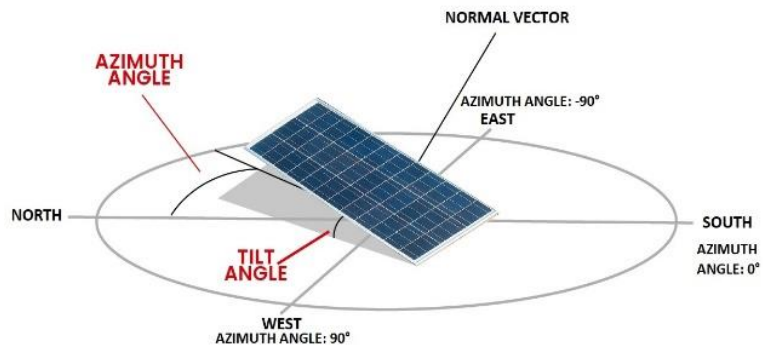

Fig. 3: Azimuth and tilt angles [19]

- Azimuth Angle $Z_{s}$

Defined as the offset angle of the south beam radiation projection on the horizontal plane [13]. As illustrated in Figure 3, the azimuth angle on south is $0^{\circ}$, the azimuth angle towards east is "_.", and towards west is " + ".

- Tilt Angle $\beta$

The optimum tilt angle for increasing the collection of solar-energy radiation differs with the year months. The annual optimum tilt angle was calculated by averaging the value of optimum tilt angles for all months of the year [13].

\subsubsection{Sun Path}

The optimal tilt angle of the panel differs with the position of the sun with respect to the earth. It differs on a daily, monthly, and yearly basis. Therefore, it is very important to maintain an optimal tilt angle of the panel throughout the year to assure maximum energy generation [16]. Figure 4 shows sun path in winter and summer, which indicates that the optimum tilt angle increases in winter months and decreases to minimum value in summer months [20].

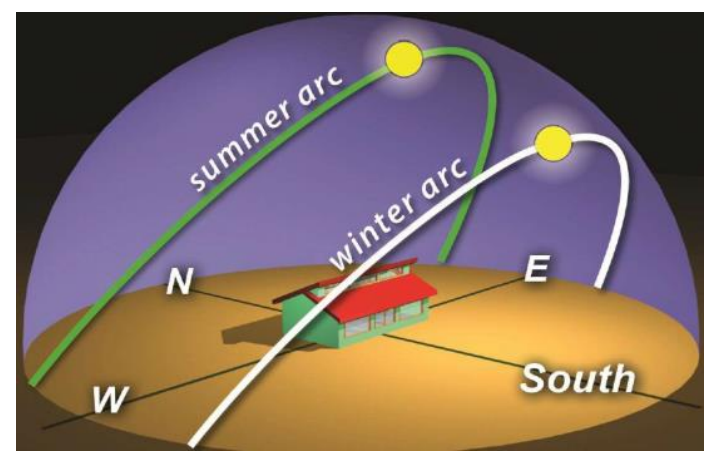

Fig. 4: Sun path in winter and summer [20]

\subsection{PVsyst Energy Simulation}

Simulation in PVsyst is executed as per the below procedures. Figure 5 shows a flowchart of the PVsyst simulation of the proposed grid-connected project.

1. Project settings

- Select the geographical site. Various sites files already exist in the PVsyst databases. After site selection, the project geographical data were uploaded.

2. PV panel orientation

In this study, doing Orientation-optimization by two scenarios, fixed tilted plane and seasonal tilt adjustment.

- Fixed tilted plane: Define the value of the yearly fixed tilt angle and azimuth angle, as shown in Figure 6.

- Seasonal tilt adjustment: Define the values of summer and winter tilt angles, and azimuth angle.

3. Designing the PV system structure, as shown in Figure 7

- PV array pre-sizing: Define the planned PV power $\left(\mathrm{kW}_{\mathrm{p}}\right)$ or available PV area.

- Select the PV module.

- Select the inverter.

- Review the array design: No of PV modules in series and no of strings.

4. Near shading

"No shading" procedure requires installing the clear available PV area.

5. Running the simulation

Simulation produces the following results in various forms of tables, graphs and summary report:

- Array nominal energy $\mathrm{E}_{\text {Nom Array }}$.

- Energy generated by the PV array system $\mathrm{E}_{\text {Array }}$.

- Energy fed to utility grid $\mathrm{E}_{\text {Grid }}$.

- PV module temperature $\mathrm{T}_{\text {Mod }}$.

- Normalized array production $\mathrm{Y}_{\mathrm{a}}$.

- Normalized system production $\mathrm{Y}_{\mathrm{f}}$.

- Reference incident energy $\mathrm{Y}_{\mathrm{r}}$.

- Performance Ratio PR.

- Global horizontal irradiation Glob ${ }_{\mathrm{Hor}}$.

- Global incident in collector plane Glob Inc.

- Effective global Glob Eff. $_{\text {. }}$.

- System Loss Diagram. 


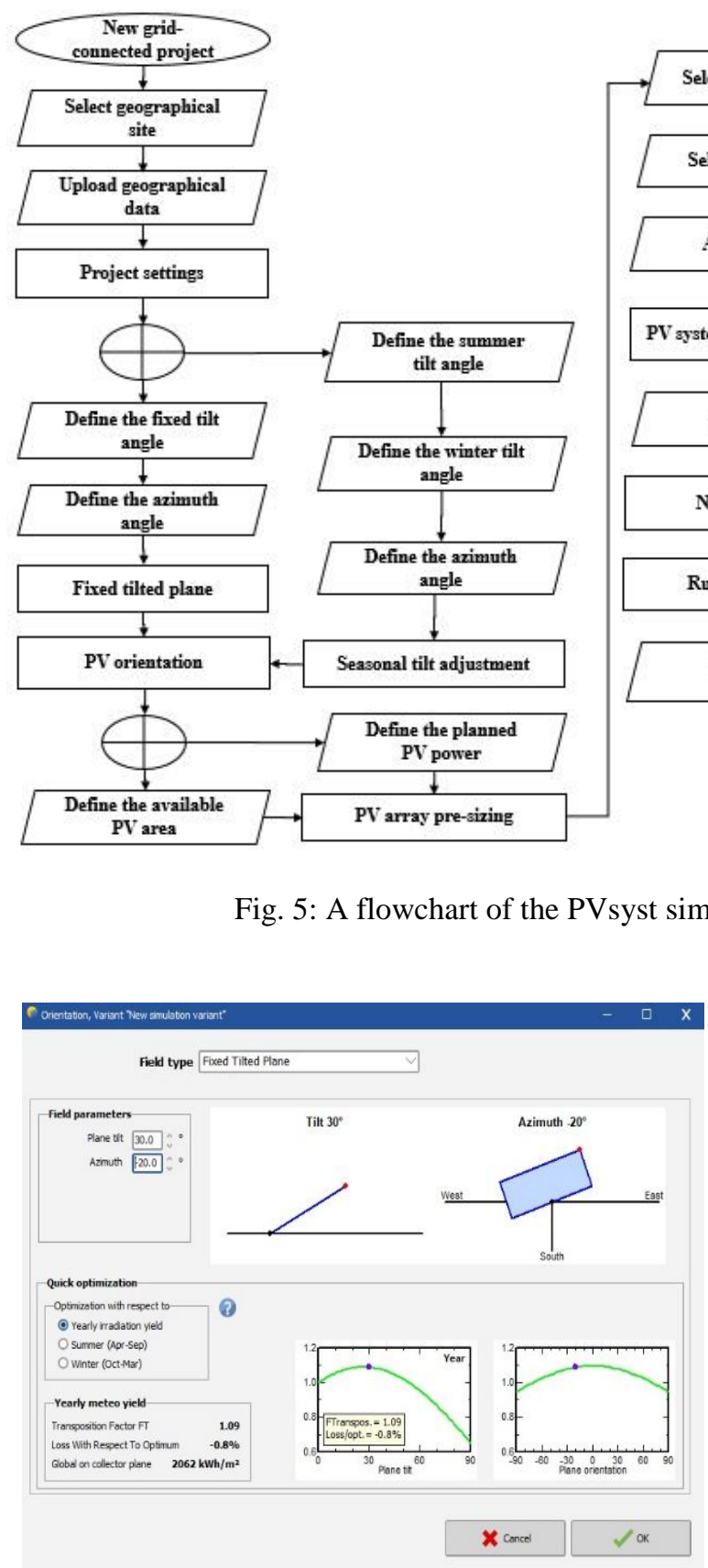

Fig. 6: Selecting PV panel orientation on PVsyst software simulation

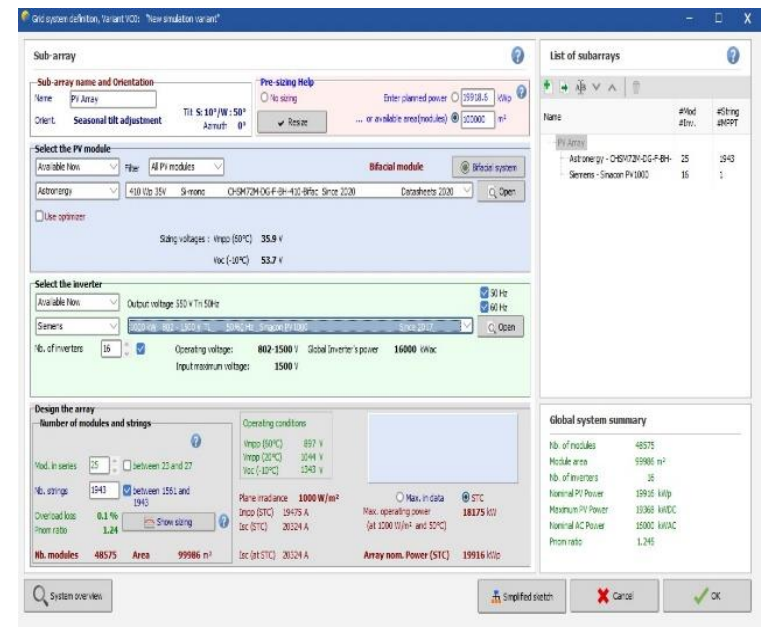

Fig. 7: Designing the PV system structure on PVsyst software simulation 


\subsection{Simulation Parameters and Indicators}

\subsubsection{Energy generated by the $P V$ array system $\left(E_{D C}\right)$}

The total daily monitored value of DC power output and the monthly DC energy generated is given by [21]:

$$
\begin{array}{ll}
E_{D C, d}=\sum_{t=1}^{t=T_{r p}} P_{D C} \times T_{r} & {[k W h]} \\
E_{D C, m}=\sum_{d=1}^{N} E_{D C, d} & {[k W h]}
\end{array}
$$

where $\mathrm{P}_{\mathrm{DC}}$ is the DC power recorded, $\mathrm{T}_{\mathrm{r}}$ is the recording time interval and $\mathrm{T}_{\mathrm{rp}}$ is the reporting period, and $\mathrm{N}$ is the number of operating days of plant in a month.

$\mathrm{E}_{\mathrm{DC}}$ in PVsyst is called $\mathrm{E}_{\text {Array }}$.

\subsubsection{Array nominal energy $\left(E_{\text {Nom Array }}\right)$}

The ideal energy for the PV array system, i.e. is the energy by the PV array system without array losses, $\mathrm{E}_{\text {Nom Array }}$ is given by [24]:

$$
E_{\text {Nom Array }}=G l o b_{\text {Eff }} \times A_{\text {Mod }} \times E f f_{\text {Mod }}
$$$$
[\mathrm{kWh}]
$$

where $\mathrm{Glob}_{\mathrm{Eff}}$ is the effective global irradiation, $\mathrm{A}_{\text {Mod }}$ is the PV module area, and $\mathrm{Eff}_{\mathrm{Mod}}$ is the efficiency of the PV module.

Thus the energy generated by the PV array system can also be given by:

$$
E_{\text {Array }}=E_{\text {Nom Array }}-E_{\text {Loss }}[\mathrm{kWh}]
$$

where $\mathrm{E}_{\mathrm{Loss}}$ is the array losses.

\subsubsection{Energy output or Energy fed to utility grid $\left(E_{A C}\right)$}

The total daily monitored value of $\mathrm{AC}$ power output and the monthly $\mathrm{AC}$ energy generated $\left(\mathrm{E}_{\mathrm{AC}}\right.$ in PVsyst is called $\left.\mathrm{E}_{\mathrm{Grid}}\right), \mathrm{E}_{\mathrm{AC}}$ is given by [21]:

$$
\begin{array}{ll}
E_{A C, d}=\sum_{t=1}^{t=T_{r p}} P_{A C} \times T_{r} & {[\mathrm{kWh}]} \\
E_{A C, m}=\sum_{d=1}^{N} E_{A C, d} & {[\mathrm{kWh}]}
\end{array}
$$

\subsection{4. $P V$ module temperature $\left(T_{M o d}\right)$}

This temperature can be determined by an energy balance between the heating of the PV module due to incident irradiance and ambient temperature, $\mathrm{T}_{\mathrm{Mod}}$ as stated below [24]:

$$
\begin{aligned}
& T_{\text {Mod }}=T_{A m b}+1 / U^{(A l p h a} \times G_{I n c} \times(1-i \\
& {\left[{ }^{\circ} \mathrm{C}\right]}
\end{aligned}
$$

Where:

- $\mathrm{T}_{\mathrm{Amb}}$ is the ambient temperature, according to the meteo data.

- $\mathrm{G}_{\mathrm{Inc}}$ is the irradiance on the module or PV array (PVsyst simulation uses Glob Eff, $_{\text {, }}$ effective irradiance taking soiling and shades into account).

- Alpha is the absorption coefficient of solar irradiation. The usual value of the Absorption coefficient Alpha is 0.9.

- $\quad$ Eff $_{\text {Mod }}$ is the PV module efficiency (related to the module area), i.e. the energy removed from the module.

- U-value: the thermal behavior is characterized by a thermal loss factor. This can be split into a constant component $\mathrm{U}_{\mathrm{c}}$ and a factor proportional to the wind velocity $U_{v}[24]$ :

$$
U=U_{c}+U_{v} \times v
$$

- $\quad \mathrm{U}_{\mathrm{c}}$ in $\left[\mathrm{W} / \mathrm{m}^{2} . \mathrm{K}\right], \mathrm{U}_{\mathrm{v}}$ in $\left[\mathrm{W} / \mathrm{m}^{2} . \mathrm{K} / \mathrm{m} / \mathrm{s}\right], \mathrm{v}=$ wind velocity in $[\mathrm{m} / \mathrm{s}]$. This $\mathrm{U}$-value is quite equivalent to the Heat transfer factor $\left[\mathrm{W} / \mathrm{m}^{2} . \mathrm{K}\right]$.

\subsubsection{Array yield $\left(Y_{a}\right)$}

The array yield $\mathrm{Y}_{\mathrm{a}}$ in PVsyst is called "Normalized array production", is the time taken by the PV to operate at nominal power generating $\mathrm{E}_{\mathrm{DC}}$. Hence it is the ratio of the daily or monthly average DC energy generated by the PV system to the rated PV power as stated below [21]:

$$
\begin{aligned}
Y_{a, d}= & E_{D C, d} / P_{P V \text { (rated) }} \\
& {[\mathrm{h} / \mathrm{d}] \text { or }[\mathrm{kWh} / \mathrm{kW} / \mathrm{day}] }
\end{aligned}
$$

where $\mathrm{P}_{\mathrm{PV} \text { (rated) }}$ is the rated $\mathrm{PV}$ power.

where $\mathrm{P}_{\mathrm{AC}}$ is the AC power recorded. 


\subsubsection{Final yield $\left(Y_{f}\right)$}

The final yield $\mathrm{Y}_{\mathrm{f}}$ in PVsyst is called "Normalized system production". The term final yield represents the time taken by the PV to generate $\mathrm{E}_{\mathrm{AC}}$ with respect to its nominal power capacity. Hence it becomes the ratio of final output power generated $\left(\mathrm{E}_{\mathrm{AC}}\right)$ to the rated PV power as specified by the manufacturer at standard temperature conditions. It depends on the mounting structure and the location. Final yield can also be calculated daily and as a monthly average and is given by [21]:

$$
\begin{aligned}
Y_{f, d}= & E_{A C, d} / P_{P V \text { (rated) }} \\
& {[h / d] \text { or }\left[k W h / k W_{p} / \text { day }\right] }
\end{aligned}
$$

\subsubsection{Reference yield $\left(Y_{r}\right)$}

The reference yield $Y_{r}$ in PVsyst is called "Reference incident energy in collector plane", is the ratio of the total incident irradiation in panel $\mathrm{H}_{t}$ $\left(\mathrm{kWh} / \mathrm{m}^{2}\right)$ to the reference irradiation $\left(\mathrm{G}_{\circ}=1 \mathrm{~kW} / \mathrm{m}^{2}\right)$, and it is expressed as [22]:

$$
Y_{r}=H_{t} / G_{\circ} \quad\left[\mathrm{kWh} / \mathrm{m}^{2} / \text { day }\right]
$$

\subsubsection{Performance ratio $(P R)$}

Performance ratio represents the effect of losses (which occur due to the effect of temperature, inverter, wiring loss, mismatch loss, Shadings, IAM, Soiling, and loss across the bypass diodes, etc.) It is the true efficiency of the system and measures the closeness to the ideal efficiency. It also describes the energy transformation in a grid connected PV system. It is thus defined as the ratio of final yield to the array yield as given by [21]:

$$
P R=Y_{f} / Y_{r}
$$

\subsubsection{Array capture loss $\left(L_{c}\right)$}

$\mathrm{L}_{\mathrm{c}}$ corresponds to the difference among reference yield $Y_{r}$ and array yield $Y_{a}$. This magnitude of the losses in a PV array are due to several factors such as the PV cell temperature rise, dust accumulation, partial shading, errors in maximum power point tracking and mismatching. $\mathrm{L}_{\mathrm{c}}$ is given by [23]:

$$
\begin{aligned}
& L_{c}=Y_{r^{-}} Y_{a} \\
& \quad[h / d] \text { or }\left[k W h / k W_{p} / d a y\right]
\end{aligned}
$$

\subsubsection{System loss $\left(L_{s}\right)$}

The inverter and the associated electrical components needed for the grid connection are factors that generate these losses. $\mathrm{L}_{\mathrm{s}}$ shows the difference among array yield $\mathrm{Y}_{\mathrm{a}}$ and final system yield $\mathrm{Y}_{\mathrm{f}} . \mathrm{L}_{\mathrm{s}}$ is given by [23]:

$$
\begin{aligned}
& L_{s}=Y_{a^{-}} Y_{f} \\
& {[h / d] \text { or }\left[k W h / k W_{p} / \text { day }\right]}
\end{aligned}
$$

\subsubsection{Total loss $(L)$}

The total loss of energy from this system L is found by taking the difference among reference yield $Y_{\mathrm{r}}$ and final yield $\mathrm{Y}_{\mathrm{f}}[23]$ :

$$
\begin{aligned}
& L=L_{c}+L_{s}=Y_{r^{-}} Y_{f} \\
& {[\mathrm{~h} / \mathrm{d}] \text { or }\left[\mathrm{kWh} / \mathrm{kW} W_{p} / \text { day }\right]}
\end{aligned}
$$

\subsubsection{Global horizontal irradiation $\left(\right.$ Glob $\left._{H o r}\right)$}

Glob $_{\mathrm{Hor}}$ is the total solar radiation incident on a horizontal surface [14].

\subsubsection{Horizontal diffuse irradiation (Diff ${ }_{\text {Hor }}$ )}

Diff $_{\text {Hor }}$ is solar radiation that does not arrive on a direct path from the sun, but has been scattered by molecules and particles in the atmosphere and comes equally from all directions.

\subsubsection{Ambient temperature $\left(T_{A m b}\right)$}

$\mathrm{T}_{\mathrm{Amb}}$ is the air temperature related to the immediate surroundings, also referred to as the ordinary temperature or the baseline temperature [24].

\subsubsection{Global incident in collector plane $\left(G l o b_{I n c}\right)$}

Glob $_{\text {Inc }}$ is computed from the horizontal global and diffuse irradiances in hourly values. It depends on the solar geometry, therefore on the geographical coordinates of course [24].

\subsubsection{Effective global (Glob $\left.{ }_{E f f}\right)$}

Effective global after all optical losses (shadings, IAM, soiling) [24]. 


\subsubsection{Solar angles}

\subsubsection{Solar declination $\delta$}

The solar declination $\delta$, is the angular distance of the sun's rays north (or south) of the equator, north declination designated as positive. As shown in Figure 8 it is the angle between the sun-earth center line and the projection of this line on the equatorial plane. The declination ranges from $0^{\circ}$ at the spring equinox to $+23.45^{\circ}$ at the summer solstice, $0^{\circ}$ at the fall equinox, and $-23.45^{\circ}$ at the winter solstice. The variation of the solar declination throughout the year is shown in Figure 9. The declination, $\delta$, in degrees for any day of the year $(\mathrm{N})$ can be calculated approximately by the equation [25]:

$$
\delta=23.45 \times \sin \left[\frac{360}{365}(284+N)\right]
$$

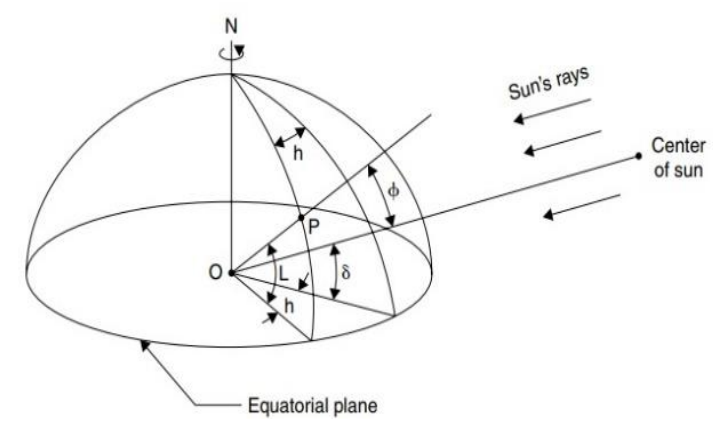

Fig. 8: Definition of solar declination, hour angle, and latitude [25]

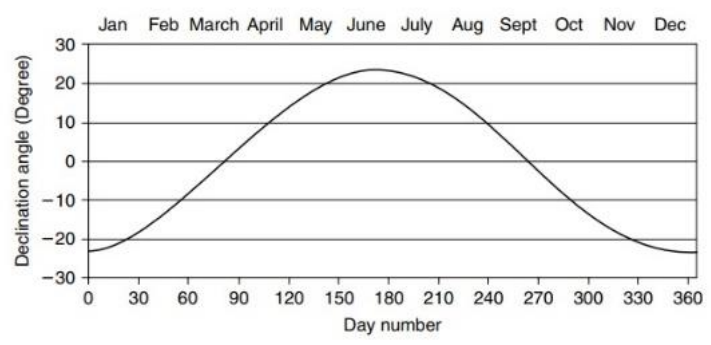

Fig. 9: Declination of the sun [25]

\subsubsection{Hour angle $h$}

The hour angle $h$, of a point on the earth's surface is defined as the angle through which the earth would turn to bring the meridian of the point directly under the sun. Figure 8 shows the hour angle of point $\mathrm{P}$ as the angle measured on the earth's equatorial plane between the projection of OP and the projection of the sun-earth center to center line. The hour angle at local solar noon is zero. Expressed symbolically, the hour angle in degrees is [25]:

$$
\begin{aligned}
& h= \pm 0.25 \text { (Number of minutes from } \\
& \text { local solar noon) }
\end{aligned}
$$

where the plus sign applies to afternoon hours and the minus sign to morning hours.

\subsubsection{Local latitude $L$}

Local latitude L, defined as the angle between a line from the center of the earth to the site of interest and the equatorial plane. Values north of the equator are positive and those south are negative, as shown in Figure 8 [25].

\subsubsection{Solar altitude angle $\alpha$ and solar zenith angle $\emptyset$}

The solar altitude angle $\alpha$, is the angle between the sun's rays and a horizontal plane, it is related to the solar zenith angle $\varnothing$, which is the angle between the sun's rays and the vertical, as shown in Figure 10 [25]. Therefore,

$$
\varnothing+\alpha=\frac{\pi}{2}=90^{\circ}
$$

The mathematical expression for the solar altitude angle and solar zenith angle is:

$$
\begin{aligned}
& \sin \alpha=\cos \varnothing= \\
& \sin L \sin \delta+\cos L \cos \delta \cos h
\end{aligned}
$$

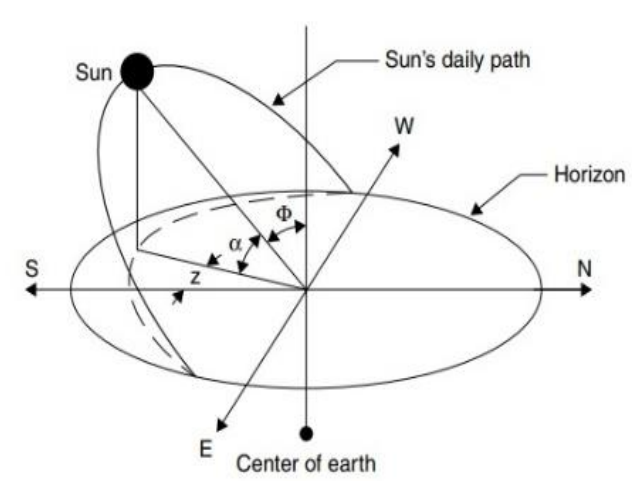

Fig. 10: Definition of solar altitude angle, solar zenith angle, and solar azimuth angle [25] 


\subsubsection{Optimum PV panels placement}

Optimum space between PV rows is a significant parameter in PV system design in order to avoid shading and avoid shading losses. Accordingly, Shadow Length should be calculated in order to place the PV panels in optimum position without shading. Dube, et al. (2018) proposed generalized Eq. 20 calculating the shadow length, where $\alpha$ is the solar altitude angle, and SL is the shadow length. Figure 11 shows the shadow length calculation [26].

$$
S L=V \times \frac{\sin \beta \times \cos \left(180^{\circ}-Z_{S}\right)}{\tan \alpha}
$$

where $\mathrm{A}$ is the horizontal projection length of the PV panel can be calculated by the equation:

$$
A=V \times \cos \beta
$$

December 21 is taken because the sun altitude angle is maximum on this day, and thus the shadow length is maximum [26]. On December 21 at Cairo Airport, the solar noon is 11:53 [27], by using Eq. 17 found the value of hour angle $h=-1.75^{\circ}$, and using
Eq. 16 found the value of declination $\delta=-23.45^{\circ}$. Then can calculate the maximum altitude angle $\alpha$ by using Eq. 19 and found that $\alpha=36.4^{\circ}$. After that using the obtained $\alpha$ value and calculating the shadow length by using Eq. 20. Table 1 shows the calculation results for horizontal projection length of the PV panel plus the shadow length $(\mathrm{SL}+\mathrm{A})$ of different tilt angles and azimuth angles when using $\alpha$ $=36.4^{\circ}$ and $\mathrm{V}=10.25 \mathrm{~m}$, found that the maximum shadow length is $17.24 \mathrm{~m}$ when azimuth angle is $0^{\circ}$ and tilt angle is $50^{\circ}$.

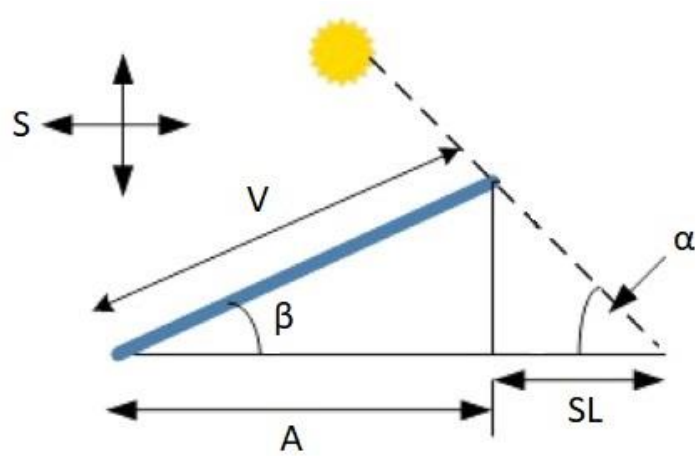

Fig. 11: Shadow length SL calculation

\begin{tabular}{|c|c|c|c|c|c|c|c|c|c|c|}
\hline $\begin{array}{c}\text { Azimuth } \\
\text { Angle }\end{array}$ & $\begin{array}{c}\text { Tilt } \\
\text { Angle } \\
0^{\circ}\end{array}$ & $\begin{array}{c}\text { Tilt } \\
\text { Angle } \\
10^{\circ}\end{array}$ & $\begin{array}{c}\text { Tilt } \\
\text { Angle } \\
20^{\circ}\end{array}$ & $\begin{array}{c}\text { Tilt } \\
\text { Angle } \\
\mathbf{3 0}^{\circ}\end{array}$ & $\begin{array}{c}\text { Tilt } \\
\text { Angle } \\
40^{\circ}\end{array}$ & $\begin{array}{c}\text { Tilt } \\
\text { Angle } \\
50^{\circ}\end{array}$ & $\begin{array}{c}\text { Tilt } \\
\text { Angle } \\
6^{\circ}\end{array}$ & $\begin{array}{c}\text { Tilt } \\
\text { Angle } \\
70^{\circ}\end{array}$ & $\begin{array}{c}\text { Tilt } \\
\text { Angle } \\
80^{\circ}\end{array}$ & $\begin{array}{c}\text { Tilt } \\
\text { Angle } \\
90^{\circ}\end{array}$ \\
\hline & \multicolumn{10}{|c|}{$\mathrm{m}$} \\
\hline $\mathbf{0}^{\circ}$ & 10.25 & 12.51 & 14.39 & 15.83 & 16.79 & 17.24 & 17.16 & 16.57 & 15.47 & 13.90 \\
\hline $\begin{array}{c}10^{\circ} \\
-10^{\circ}\end{array}$ & 10.25 & 12.47 & 14.31 & 15.72 & 16.65 & 17.08 & 16.98 & 16.37 & 15.26 & 13.69 \\
\hline $\begin{array}{r}20^{\circ} \\
-20^{\circ}\end{array}$ & 10.25 & 12.36 & 14.10 & 15.41 & 16.25 & 16.60 & 16.44 & 15.78 & 14.64 & 13.06 \\
\hline $\begin{array}{l}30^{\circ} \\
-30^{\circ}\end{array}$ & 10.25 & 12.18 & 13.75 & 14.90 & 15.59 & 15.81 & 15.55 & 14.82 & 13.63 & 12.04 \\
\hline $\begin{array}{l}40^{\circ} \\
-40^{\circ}\end{array}$ & 10.25 & 11.94 & 13.27 & 14.20 & 14.70 & 14.75 & 14.35 & 13.51 & 12.27 & 10.65 \\
\hline $\begin{array}{l}50^{\circ} \\
-50^{\circ}\end{array}$ & 10.25 & 11.65 & 12.69 & 13.35 & 13.60 & 13.43 & 12.86 & 11.90 & 10.58 & 8.94 \\
\hline $\begin{array}{l}60^{\circ} \\
-60^{\circ}\end{array}$ & 10.25 & 11.30 & 12.01 & 12.35 & 12.32 & 11.91 & 11.14 & 10.04 & 8.62 & 6.95 \\
\hline $\begin{array}{l}70^{\circ} \\
-70^{\circ}\end{array}$ & 10.25 & 10.92 & 11.26 & 11.25 & 10.91 & 10.23 & 9.24 & 7.97 & 6.46 & 4.75 \\
\hline $\begin{array}{l}80^{\circ} \\
-80^{\circ}\end{array}$ & 10.25 & 10.51 & 10.46 & 10.08 & 9.40 & 8.44 & 7.22 & 5.77 & 4.16 & 2.41 \\
\hline $\begin{array}{c}90^{\circ} \\
-90^{\circ}\end{array}$ & 10.25 & 10.09 & 9.63 & 8.88 & 7.85 & 6.59 & 5.13 & 3.51 & 1.78 & 0.00 \\
\hline
\end{tabular}

Table 1. The calculation results for horizontal projection length of the PV panel plus the shadow length $(\mathrm{SL}+\mathrm{A})$ 


\subsubsection{Near shadings}

The treatment of near shadings can be done with a perspective description of the full PV system. In PVsyst using the "no shading" option and inputting the PV area value $\left(\mathrm{m}^{2}\right)$, PVsyst will not take any losses in shading. This requires first calculating the shadow length and locating the PV panels in optimal placement without shading, and then get the suitable PV area or the suitable PV power [24].

Here in this study "no shading" was used. The shadow length was calculated plus the horizontal projection length of the PV panel $(\mathrm{SL}+\mathrm{A})$, and it was found that the maximum $\mathrm{SL}+\mathrm{A}=17.25 \mathrm{~m}$, as discussed in Section 2.4.18. A distance $30 \mathrm{~m}$ was selected between the PV rows of the plant as discussed in Section 2.1, which confirmed that there is no shading on the PV panels, and so there is no shading losses.

\subsubsection{The standard test conditions "STC"}

STC for the specification of PV modules are normalized operating conditions when testing the module. They are defined as [24]:

○ $1000 \mathrm{~W} / \mathrm{m}^{2}$ Irradiance (global when in outdoor conditions).

- $25^{\circ} \mathrm{C}$ Module temperature.

○ AM 1.5 Spectrum, i.e. a normalized solar spectrum corresponding to the crossing of 1.5 times the "normal" atmosphere [24].

Figure 12 shows the results for $\mathrm{STC}\left(\mathrm{T}=25^{\circ} \mathrm{C}\right.$, $\mathrm{G}_{\circ}=1,000 \mathrm{~W} / \mathrm{m}^{2}, \quad \mathrm{AM}=1.5$ ) of the selected $\mathrm{PV}$ module, where the PV module specifications are:

- Reference temperature $\mathrm{T}_{\text {Ref }}=25^{\circ} \mathrm{C}$.

- Reference irradiance $\mathrm{G}_{\circ}=1,000 \mathrm{~W} / \mathrm{m}^{2}$.

- Maximum power point voltage $\mathrm{V}_{\mathrm{mpp}}=41.0 \mathrm{~V}$.

- $\quad$ Maximum power point current $\mathrm{I}_{\mathrm{mpp}}=10.02 \mathrm{~A}$.

- $\quad$ Maximum power $\mathrm{P}_{\mathrm{mpp}}=410.2 \mathrm{~W}_{\mathrm{p}}$.

- $\quad$ Nominal power $\mathrm{P}_{\text {Nom }}=410 \mathrm{~W}_{\mathrm{p}}$.

- $\quad$ Efficiency (/ Module area) Eff $_{\text {Mod }}=19.9 \%$.

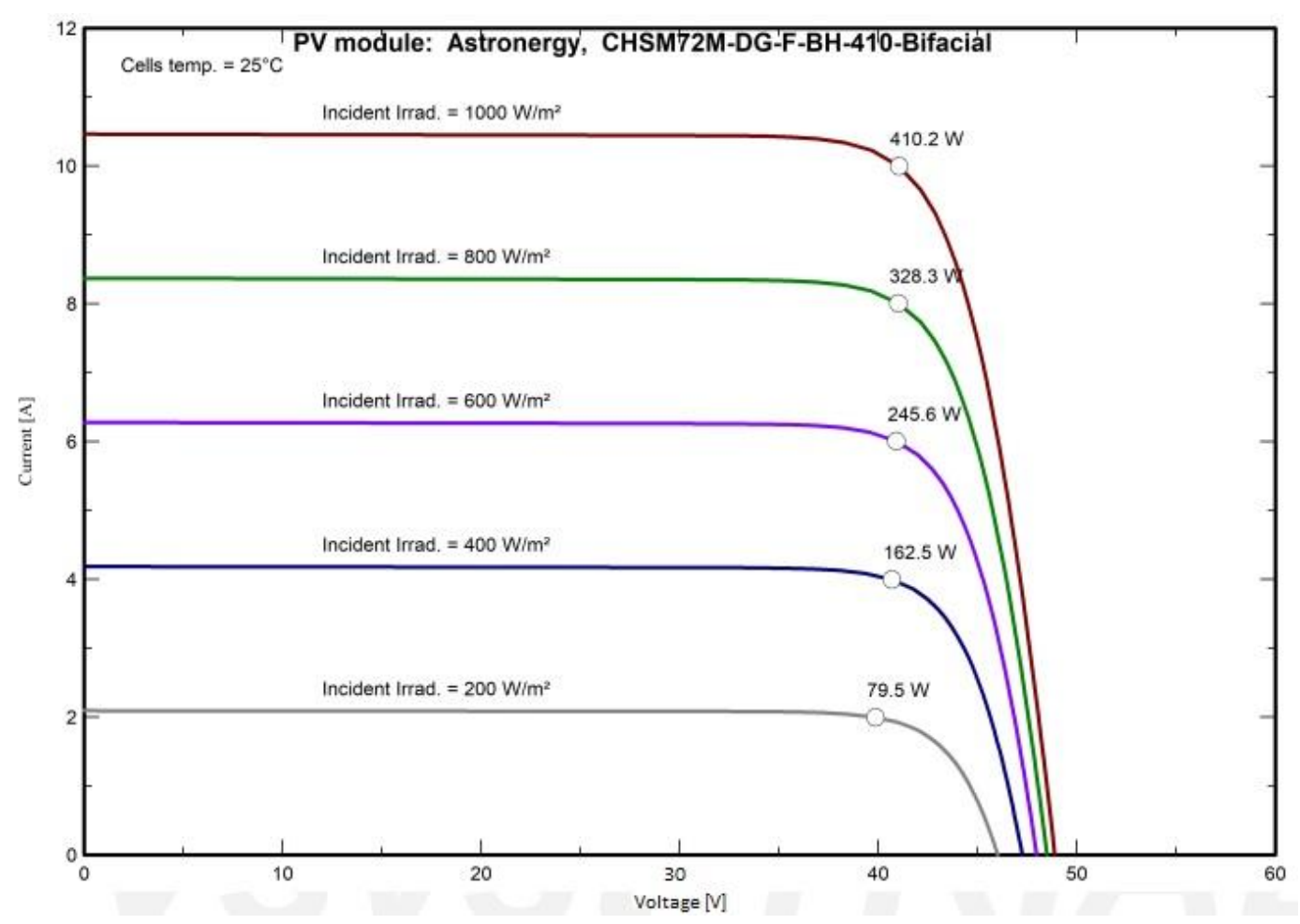

Fig. 12: The results for STC of the selected PV module 


\subsubsection{PV module nominal power}

Nominal power is the rated power specified by the manufacturer at STC. It will be used to determine the "installed power" of systems, which is involved namely in the Performance Ratio [24].

\subsubsection{MPPT inputs of the inverter}

MPPT stands for Maximum Power Point Tracker. It is a circuit typically a DC to DC converter. Its mission to maximize the energy available from the connected solar module arrays at any time during its operation [24].

\subsubsection{Array losses}

\subsubsection{Array incidence loss (IAM)}

The incidence effect (the designated term is IAM, for "Incidence Angle Modifier") corresponds to the decrease of the irradiance really reaching the PV cells surface, with respect to irradiance under normal incidence. This decrease is mainly due to reflections on the glass cover, which increases with the incidence angle $\theta$ [24].

PVsyst uses an IAM function, which describes the deficit of transmission as a function of the incidence angle [24].

- Fresnel's laws

In principle, this phenomenon obeys the Fresnel's Laws describing transmission and reflections at the interface of two transparent materials of different reflections indexes $n_{1}$ and $\mathrm{n}_{2}$. These laws allow to calculate the light effectively reaching the cell's surface below the protective layer (usually glass), as a function of the incidence angle. Then it is able to add an anti-reflective coating on the top interface airglass. This thin layer has a lower refraction index than the glass, which limits the first reflection [24].

\section{- ASHRAE Parametrization}

In practice, this IAM function is often approached by using the "ASHRAE" parametrization depending on one only parameter incidence angle $\theta$ [24]:

$$
F_{I A M}=1-b_{o} \times\left(\frac{1}{\cos \theta}-1\right)
$$

For single-glazed thermal solar modules, the usually accepted value for $b_{o}$ is of the order of 0.1. But in a PV module, the lower interface, in contact with the cell, presents a high refraction index and our specific measurements on real crystalline modules actually indicate a value of $\mathrm{b}_{\mathrm{o}}=0.05$ [24].

PVsyst gives the opportunity of specifying the kind of glass interface (Normal glass, Anti-reflective coating, structured glass or plastic). And attributes a default model according to this specification [24].

\subsubsection{Soiling losses}

Accumulation of dirt and its effect on the system performance is an uncertainty which strongly depends on the environment of the system, raining conditions, etc. Therefore PVsyst allows the definition of soiling loss factors in monthly values. During the simulation, the soiling loss is accounted for as an irradiance loss [24].

\subsubsection{Irradiance losses}

In PVsyst, the evaluation of the "Losses" of a PV array, takes as starting point the energy which would be produced if the system worked always at STC conditions $\left(1000 \mathrm{~W} / \mathrm{m}^{2}, 25^{\circ} \mathrm{C}, \mathrm{AM} 1.5\right)$ [24].

\subsubsection{Thermal losses}

The thermal behavior of the field, which strongly influences the electrical performances, is determined by an energy balance between ambient temperature and the heating of the PV module due to incident irradiance, as discussed in Section 2.4.4 [24].

\subsubsection{Module quality losses}

PVsyst initializes the "Module Quality Loss" according to the PV module manufacturer's tolerance specification. PVsyst chooses a quarter of the difference between these values. For example, with $3,+3 \%$, it will be $1.5 \%$, and with positive sorting 0 , $+3 \%$, it will be $-0.75 \%$ (i.e. a negative loss value, representing a gain) [24].

\subsubsection{Array mismatch losses}

The mismatch loss is defined as the difference between the sum of all $\mathrm{P}_{\mathrm{mpp}}$ of each independent sub- 
module, and the $\mathrm{P}_{\mathrm{mpp}}$ of the resulting $\mathrm{I} / \mathrm{V}$ characteristics of the array. The reasons for the mismatch are that the real modules are never quite identical. At the output of the factory, the modules are sorted according to the parameters measured by a flash-test. They are attributed to their power class. Nowadays each power class ranges from 1.5 to $2 \%$ [24].

\subsubsection{Strings mismatch losses}

The mismatch parameter concerns the electrical differences between the modules in an array. It reflects the fact that in a string of modules (or cells), the lowest current drives the current of the whole string [24].

\subsubsection{Ohmic wiring losses}

The ohmic resistance of the wiring circuit induces losses between the power available from the modules and the power at the terminals of the sub-array. The relevant parameter for the simulation is the $\mathrm{R}_{\mathrm{w}}$ value, which is an equivalent resistance of the wires. The $\mathrm{R}_{\mathrm{w}}$ value evaluation will highly depend on the subarray structure, and defining $\mathrm{R}_{\mathrm{w}}$ value as per the equation below [24]:

$$
E_{\text {Loss }}=R_{w} \times I_{\text {array }}^{2}
$$

\subsubsection{Inverter losses}

The power difference between the mpp of the arrays I/V curve and the effective power of this operating point is accounted as inverter loss [24]:

- Inverter Loss during operation: The inefficiency loss, computed according to the efficiency curve. Inverter Loss due to power threshold: Loss when the power of the array is not sufficient for starting the inverter.

- Inverter Loss over nominal inverter power, i.e. overload loss.

- Inverter Loss due to voltage threshold, i.e. when the array mpp voltage is below $\mathrm{V}_{\text {mppMin }}$.

- Inverter Loss over nominal inverter voltage, i.e. when the array mpp voltage is over $\mathrm{V}_{\text {mppMax }}$.

- Inverter Loss due to the maximum input current.

\subsubsection{Loss diagram}

The loss diagram provides a quick and insight look into the quality of a PV system design, by identifying the main sources of losses [24].

The array losses start from the evaluation of the nominal energy, using the global effective irradiance and the array nominal efficiency at STC. Then it gives the detail of the PV model behavior according to the environmental variables [24].

\subsection{Energy analysis scenarios}

After defining the PV plant area at Cairo International Airport, the PVsyst was used for energy simulation. Several optimization simulations were performed in order to obtain the optimal orientation and hence obtain a higher power result.

The analysis was done through two scenarios. The first scenario was applied to obtain the optimal yearly fixed tilt angle and the optimal azimuth angle. The second scenario was applied to obtain the optimal seasonal dual tilt angles and the optimal azimuth angle.

Orientation-optimization simulation aims to increase the value of module temperature $\mathrm{T}_{\mathrm{Mod}}$, and $\mathrm{Glob}_{\text {Inc }}$ which leads to an increase in the values of Glob $_{\mathrm{Eff}}, \mathrm{E}_{\text {Nom Array }}, \mathrm{E}_{\text {Array }}, \mathrm{E}_{\text {Grid }}, \mathrm{Y}_{\mathrm{r}}, \mathrm{Y}_{\mathrm{a}}$, and $\mathrm{Y}_{\mathrm{f}}$.

\section{Results \& Discussion}

This section represents the optimization simulation results using a PV panel $410 \mathrm{~W}_{\mathrm{p}}$ for the two scenarios that were mentioned in Section 2.5.

The first scenario, obtaining the optimal yearly fixed tilt angle and optimal azimuth angle: The energy simulation was applied with different fixed tilt angles $\left(0^{\circ}, 10^{\circ}, 20^{\circ}, 30^{\circ}, 40^{\circ}, 50^{\circ}, 60^{\circ}, 70^{\circ}, 80^{\circ}, 90^{\circ}\right)$ for different azimuth angles $\left(0^{\circ},-20^{\circ},-40^{\circ},-60^{\circ}\right.$, $80^{\circ},-90^{\circ},-110^{\circ},-130^{\circ},-150^{\circ},-170^{\circ},-180^{\circ}$ or $180^{\circ}$, $170^{\circ}, 150^{\circ}, 130^{\circ}, 110^{\circ}, 90^{\circ}, 80^{\circ}, 60^{\circ}, 40^{\circ}, 20^{\circ}$ ).

The second scenario, obtaining the optimal seasonal dual tilt angles: It was implemented by applying summer and winter dual-tilt angles selected for the azimuth angles selected in order to obtain the optimal seasonal dual tilt angles and the optimal azimuth angle.

\subsection{First scenario, getting optimal yearly fixed tilt angle and optimal azimuth angle}

The simulation was performed by applying PVsyst using PV panel $410 \mathrm{~W}_{\mathrm{p}}$ for the mentioned fixed tilt and azimuth angles, and the results were obtained. Table 2 and Table 3 present the results of average module temperature and energy injected into grid for Cases 1-200 for all specified azimuth and tilt angles. 
Figures 13 and 14 show the temperature contour and output energy graph for these results. It can be seen that the $0^{\circ}$ tilt angle results are the same because the PV panel will be in a horizontal plane, and its performance will be the same when choosing different azimuth angles. The highest results of average $T_{\text {Mod }}$ and $E_{\text {Grid }}$ from the fixed tilt angle are $30^{\circ}, 20^{\circ}, 40^{\circ}, 10$, and $50^{\circ}$, and the best result is $30^{\circ}$. This is when using $0^{\circ}$ azimuth angle. Results of $10^{\circ}$, $20^{\circ}, 30^{\circ}, 40^{\circ}$, and $50^{\circ}$ tilt angles work best when the azimuth angle value is specified as $-40^{\circ}, 0^{\circ}$, and $40^{\circ}$. However, when using other azimuth angles between $-40^{\circ}$ and $-180^{\circ}$, and between $40^{\circ}$ and 180 $\circ$, the results change to become poor. Moreover, results for $60^{\circ}, 70^{\circ}, 80^{\circ}$ and $90^{\circ}$ tilt angles are not recommended when using different azimuth angles. The output parameters of Glob Inc $_{1}$, Glob $_{\text {Eff }}, \mathrm{E}_{\text {Nom Array }}$, $E_{\text {Array }}, E_{\text {Grid }}, Y_{r}, Y_{a}$, and $Y_{f}$ are generally have the same behavior as shown in Figure 14.

Figures 15 and 16 show PVsyst results of average $\mathrm{T}_{\text {Mod }}$ for Case 73 (tilt angle is $20^{\circ}$ and azimuth angle is $-60^{\circ}$ ), and Case 114 (tilt angle is $30^{\circ}$ and azimuth angle is $0^{\circ}$ ). The results show that the temperature values of Case 114 are higher than values of Case 73, where the average annual $\mathrm{T}_{\text {Mod }}$ value of Case 114 is $41.78^{\circ} \mathrm{C}$ and Case 73 is $40.64^{\circ} \mathrm{C}$. Figures 17 and 18 show the PVsyst results of Glob Inc $_{\text {In }}$ for Case 73 and Case 114 , the values are $1,957.2 \mathrm{kWh} / \mathrm{m}^{2}$ and $2,072.9 \mathrm{kWh} / \mathrm{m}^{2}$. Figures 19 and 20 show the PVsyst results of normalized productions for Case 73 and Case 114, the values of $Y_{r}, Y_{a}$, and $Y_{f}$ for Case 73 are $5.36 \mathrm{kWh} / \mathrm{m}^{2} /$ day, $4.61 \mathrm{kWh} / \mathrm{kW}_{\mathrm{p}} /$ day and $5.54 \mathrm{kWh} / \mathrm{kW}_{\mathrm{p}} /$ day, and for Case 114 are 5.68 $\mathrm{kWh} / \mathrm{m}^{2} /$ day, $4.88 \mathrm{kWh} / \mathrm{kW}_{\mathrm{p}} /$ day and 4.81 $\mathrm{kWh} / \mathrm{kW}_{\mathrm{p}} /$ day. Figures 21 and 22 show the PVsyst loss diagram for Case 73 and Case 114. The values of Glob $_{\mathrm{Eff}}, \mathrm{E}_{\text {Nom Array }}, \mathrm{E}_{\text {Array }}$, and $\mathrm{E}_{\text {Grid }}$ in Case 73 are $1,902 \mathrm{kWh} / \mathrm{m}^{2}, 37,896 \mathrm{MWh}, 33,495 \mathrm{MWh}$, and $33,019 \mathrm{MWh}$, and in Case 114 are 2,020.6 kWh $/ \mathrm{m}^{2}$, 40,257 MWh, 35,456 MWh, and 34,950 MWh.

It can be seen that the Case 114 values are higher than Case 73 , the average $\mathrm{T}_{\text {Mod }}$ is $41.68^{\circ} \mathrm{C}$ and Glob $_{\text {Inc }}$ increased by $9.2 \%$ but in Case 73 , the average $\mathrm{T}_{\text {Mod }}$ is $40.64^{\circ} \mathrm{C}$ and $\mathrm{Glob}_{\text {Inc }}$ increased by $3.1 \%$. In this scenario the best values is from Case
114 when tilt angle 30 and azimuth 0 are used.

\subsection{Second scenario, getting optimal seasonal dual tilt angles}

As mentioned in Section 2.2.2, the position of the Sun changes throughout the year and the tilt angle in winter is preferred to be higher than it is in summer. PVsyst is a multi-simulation analysis, giving the ability to simulate energy analysis with seasonal dual tilt angles.

In this scenario, the energy was analyzed with the selection of two seasonal dual tilt angles (summer $10^{\circ}$ and winter $50^{\circ}$ ) and (summer $20^{\circ}$ and winter $40^{\circ}$ ), and selection of different azimuth angles $0^{\circ}$, $20^{\circ},-40^{\circ},-80^{\circ}, 80^{\circ}, 40^{\circ}, 20^{\circ}$. Table 4 and Table 5 present the results of average module temperature and energy injected into grid for Cases 201-214 for the mentioned azimuth and tilt angles. Figures 23 and 24 show the temperature contour and output energy graph for these results. It can be seen that the average $\mathrm{T}_{\mathrm{Mod}}$ and $\mathrm{E}_{\text {Grid }}$ results for seasonal dual tilt angles, summer $10^{\circ}$ and winter $50^{\circ}$, are better than $20^{\circ}$ and $40^{\circ}$, but the results are very close to each other. When seasonal dual tilt angles are used, the results of average $\mathrm{T}_{\mathrm{Mod}}$ and $\mathrm{E}_{\text {Grid }}$ are better, and they increase in a higher proportion, which results in higher power generation. The output parameters of Glob $_{\text {Inc }}$, Glob $_{\text {Eff }}, E_{\text {Nom Array }}, E_{\text {Array }}, E_{\text {Grid }}, Y_{r}, Y_{a}$, and $Y_{f}$ are generally have the same behavior as shown in Figure 24.

Figures 25-28 show PVsyst results of average

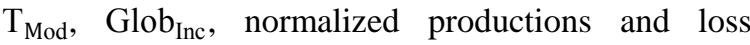
diagram for Case 207 (summer and winter tilt angles $10^{\circ}$ and $50^{\circ}$, and azimuth angle $0^{\circ}$ ). The average $\mathrm{T}_{\text {Mod }}$ is $42.59^{\circ} \mathrm{C}$. The values for $\mathrm{Y}_{\mathrm{r}}, \mathrm{Y}_{\mathrm{a}}$, and $\mathrm{Y}_{\mathrm{f}}$ are $5.90 \mathrm{kWh} / \mathrm{m}^{2} /$ day, $5.07 \mathrm{kWh} / \mathrm{kW}_{\mathrm{p}} /$ day and 5 $\mathrm{kWh} / \mathrm{kW}_{\mathrm{p}} /$ day. The values for Glob $\mathrm{Inc}_{\text {Inc }}, \mathrm{Glob}_{\mathrm{Eff}}$, $\mathrm{E}_{\text {Nom Array }}, \mathrm{E}_{\text {Array }}$ and $\mathrm{E}_{\text {Grid }}$ are $2,152.9 \mathrm{kWh} / \mathrm{m}^{2}$, 2,105.3 $\mathrm{kWh} / \mathrm{m}^{2}$, 41,945 MWh, 36,859 MWh, and 36,332 MWh. This case gives the best values, which increased $\mathrm{Glob}_{\text {Inc }}$ by $13.5 \%$. 
Table 2. Results of average module temperature $\mathrm{T}_{\mathrm{Mod}}$ with different fixed tilt angles and different azimuth angles

\begin{tabular}{|c|c|c|c|c|c|c|c|c|c|c|c|}
\hline \multirow[t]{2}{*}{ Case No. } & \multirow[t]{2}{*}{$\begin{array}{c}\text { Azimuth } \\
\text { Angle }\end{array}$} & $\begin{array}{c}\text { Tilt } \\
\text { Angle } \\
0^{\circ}\end{array}$ & $\begin{array}{c}\text { Tilt } \\
\text { Angle } \\
10^{\circ}\end{array}$ & $\begin{array}{c}\text { Tilt } \\
\text { Angle } \\
\mathbf{2 0}^{\circ}\end{array}$ & $\begin{array}{c}\text { Tilt } \\
\text { Angle } \\
\mathbf{3 0}^{\circ}\end{array}$ & $\begin{array}{c}\text { Tilt } \\
\text { Angle } \\
40^{\circ}\end{array}$ & $\begin{array}{c}\text { Tilt } \\
\text { Angle } \\
50^{\circ}\end{array}$ & $\begin{array}{c}\text { Tilt } \\
\text { Angle } \\
60^{\circ}\end{array}$ & $\begin{array}{c}\text { Tilt } \\
\text { Angle } \\
7^{\circ}\end{array}$ & $\begin{array}{c}\text { Tilt } \\
\text { Angle } \\
80^{\circ}\end{array}$ & $\begin{array}{c}\text { Tilt } \\
\text { Angle } \\
90^{\circ}\end{array}$ \\
\hline & & \multicolumn{10}{|c|}{${ }^{\circ} \mathrm{C}$} \\
\hline Case 01-10 & $\begin{array}{l}-180^{\circ} \\
+180^{\circ}\end{array}$ & 39.98 & 38.67 & 36.97 & 35.00 & 33.06 & 31.24 & 29.59 & 28.23 & 27.33 & 26.98 \\
\hline Case 11-20 & $-170^{\circ}$ & 39.98 & 38.70 & 37.01 & 35.06 & 33.13 & 31.34 & 29.72 & 28.38 & 27.52 & 27.14 \\
\hline Case 21-30 & $-150^{\circ}$ & 39.98 & 38.85 & 37.36 & 35.62 & 33.82 & 32.14 & 30.69 & 29.54 & 28.70 & 28.08 \\
\hline Case 31-40 & $-130^{\circ}$ & 39.98 & 39.14 & 37.97 & 36.59 & 35.13 & 33.71 & 32.42 & 31.28 & 30.30 & 29.44 \\
\hline Case 41-50 & $-110^{\circ}$ & 39.98 & 39.51 & 38.74 & 37.75 & 36.64 & 35.47 & 34.30 & 33.14 & 32.02 & 30.93 \\
\hline Case 51-60 & $-90^{\circ}$ & 39.98 & 39.92 & 39.55 & 38.92 & 38.08 & 37.09 & 35.98 & 34.78 & 33.51 & 32.23 \\
\hline Case 61-70 & $-80^{\circ}$ & 39.98 & 40.13 & 39.94 & 39.46 & 38.73 & 37.80 & 36.70 & 35.46 & 34.12 & 32.74 \\
\hline Case 71-80 & $-60^{\circ}$ & 39.98 & 40.51 & 40.64 & 40.42 & 39.85 & 38.99 & 37.84 & 36.48 & 34.97 & 33.36 \\
\hline Case 81-90 & $-40^{\circ}$ & 39.98 & 40.81 & 41.20 & 41.15 & 40.70 & 39.82 & 38.61 & 37.08 & 35.34 & 33.46 \\
\hline Case E91-100 & $-20^{\circ}$ & 39.98 & 41.00 & 41.55 & 41.63 & 41.21 & 40.32 & 39.01 & 37.32 & 35.32 & 33.16 \\
\hline Case 101-110 & $\mathbf{0}^{\circ}$ & 39.98 & 41.07 & 41.68 & 41.78 & 41.37 & 40.47 & 39.11 & 37.32 & 35.20 & 32.94 \\
\hline Case 111-120 & $20^{\circ}$ & 39.98 & 41.00 & 41.54 & 41.61 & 41.20 & 40.31 & 38.99 & 37.29 & 35.29 & 33.14 \\
\hline Case 121-130 & $40^{\circ}$ & 39.98 & 40.80 & 41.18 & 41.13 & 40.67 & 39.79 & 38.57 & 37.05 & 35.30 & 33.41 \\
\hline Case 131-140 & $60^{\circ}$ & 39.98 & 40.50 & 40.63 & 40.39 & 39.82 & 38.95 & 37.79 & 36.44 & 34.92 & 33.27 \\
\hline Case 141-150 & $\mathbf{8 0}^{\circ}$ & 39.98 & 40.12 & 39.92 & 39.44 & 38.70 & 37.76 & 36.66 & 35.39 & 34.07 & 32.67 \\
\hline Case 151-160 & $90^{\circ}$ & 39.98 & 39.91 & 39.53 & 38.90 & 38.06 & 37.06 & 35.94 & 34.73 & 33.45 & 32.18 \\
\hline Case 161-170 & $110^{\circ}$ & 39.98 & 39.50 & 38.72 & 37.74 & 36.63 & 35.46 & 34.27 & 33.10 & 31.97 & 30.88 \\
\hline Case 171-180 & $130^{\circ}$ & 39.98 & 39.13 & 37.96 & 36.59 & 35.13 & 33.71 & 32.41 & 31.26 & 30.27 & 29.39 \\
\hline Case 181-190 & $150^{\circ}$ & 39.98 & 38.85 & 37.36 & 35.62 & 33.83 & 32.14 & 30.68 & 29.52 & 28.68 & 28.06 \\
\hline Case 191-200 & $170^{\circ}$ & 39.98 & 38.69 & 37.01 & 35.07 & 33.14 & 31.34 & 29.71 & 28.37 & 27.51 & 27.13 \\
\hline
\end{tabular}

Table 3. Results of energy injected into Grid $\mathrm{E}_{\mathrm{Grid}}$ with different fixed tilt angles and different azimuth angles

\begin{tabular}{|c|c|c|c|c|c|c|c|c|c|c|c|}
\hline \multirow[t]{2}{*}{ Case No. } & \multirow[t]{2}{*}{$\begin{array}{c}\text { Azimuth } \\
\text { Angle }\end{array}$} & $\begin{array}{c}\text { Tilt } \\
\text { Angle } \\
0^{\circ} \\
\end{array}$ & $\begin{array}{c}\text { Tilt } \\
\text { Angle } \\
10^{\circ} \\
\end{array}$ & $\begin{array}{c}\text { Tilt } \\
\text { Angle } \\
20^{\circ} \\
\end{array}$ & $\begin{array}{c}\text { Tilt } \\
\text { Angle } \\
3^{\circ} \\
\end{array}$ & $\begin{array}{c}\text { Tilt } \\
\text { Angle } \\
40^{\circ} \\
\end{array}$ & $\begin{array}{c}\text { Tilt } \\
\text { Angle } \\
50^{\circ} \\
\end{array}$ & $\begin{array}{c}\text { Tilt } \\
\text { Angle } \\
60^{\circ} \\
\end{array}$ & $\begin{array}{c}\text { Tilt } \\
\text { Angle } \\
7^{\circ} \\
\end{array}$ & $\begin{array}{c}\text { Tilt } \\
\text { Angle } \\
80^{\circ} \\
\end{array}$ & $\begin{array}{c}\text { Tilt } \\
\text { Angle } \\
90^{\circ} \\
\end{array}$ \\
\hline & & \multicolumn{10}{|c|}{ GWh/yr } \\
\hline Case 01-10 & $\begin{array}{l}-180^{\circ} \\
+180^{\circ}\end{array}$ & 31.84 & 29.56 & 26.54 & 23.03 & 19.56 & 16.32 & 13.32 & 10.79 & 9.11 & 8.44 \\
\hline Case 11-20 & $-170^{\circ}$ & 31.84 & 29.60 & 26.64 & 23.17 & 19.72 & 16.51 & 13.56 & 11.09 & 9.47 & 8.75 \\
\hline Case 21-30 & $-150^{\circ}$ & 31.84 & 29.89 & 27.27 & 24.19 & 20.98 & 17.96 & 15.34 & 13.24 & 11.70 & 10.55 \\
\hline Case 31-40 & $-130^{\circ}$ & 31.84 & 30.39 & 28.35 & 25.93 & 23.35 & 20.83 & 18.51 & 16.47 & 14.68 & 13.09 \\
\hline Case 41-50 & $-110^{\circ}$ & 31.84 & 31.05 & 29.71 & 27.98 & 26.04 & 23.99 & 21.92 & 19.86 & 17.85 & 15.88 \\
\hline Case 51-60 & $-90^{\circ}$ & 31.84 & 31.77 & 31.12 & 30.02 & 28.57 & 26.85 & 24.92 & 22.83 & 20.59 & 18.30 \\
\hline Case 61-70 & $-80^{\circ}$ & 31.84 & 32.12 & 31.80 & 30.97 & 29.71 & 28.10 & 26.21 & 24.05 & 21.69 & 19.26 \\
\hline Case 71-80 & $-60^{\circ}$ & 31.84 & 32.77 & 33.02 & 32.63 & 31.67 & 30.21 & 28.25 & 25.92 & 23.29 & 20.43 \\
\hline Case 81-90 & $-40^{\circ}$ & 31.84 & 33.29 & 33.98 & 33.91 & 33.16 & 31.68 & 29.64 & 27.04 & 23.99 & 20.64 \\
\hline Case E91-100 & $-20^{\circ}$ & 31.84 & 33.62 & 34.57 & 34.73 & 34.04 & 32.57 & 30.37 & 27.47 & 23.98 & 20.11 \\
\hline Case 101-110 & $\mathbf{0}^{\circ}$ & 31.84 & 33.72 & 34.76 & 34.95 & 34.28 & 32.80 & 30.52 & 27.45 & 23.73 & 19.66 \\
\hline Case 111-120 & $20^{\circ}$ & 31.84 & 33.58 & 34.50 & 34.62 & 33.92 & 32.43 & 30.22 & 27.31 & 23.81 & 19.96 \\
\hline Case 121-130 & $40^{\circ}$ & 31.84 & 33.22 & 33.83 & 33.18 & 32.91 & 31.43 & 29.35 & 26.74 & 23.70 & 20.37 \\
\hline Case 131-140 & $60^{\circ}$ & 31.84 & 32.67 & 32.84 & 32.38 & 31.37 & 29.86 & 27.87 & 25.54 & 22.91 & 20.07 \\
\hline Case $141-150$ & $80^{\circ}$ & 31.84 & 32.01 & 31.60 & 30.70 & 29.38 & 27.73 & 25.82 & 23.63 & 21.32 & 18.88 \\
\hline Case 151-160 & $90^{\circ}$ & 31.84 & 31.66 & 30.92 & 29.75 & 28.25 & 26.49 & 24.54 & 22.43 & 20.21 & 17.97 \\
\hline Case 161-170 & $110^{\circ}$ & 31.84 & 30.95 & 29.53 & 27.74 & 25.76 & 23.68 & 21.59 & 19.54 & 17.45 & 15.59 \\
\hline Case 171-180 & $130^{\circ}$ & 31.84 & 30.31 & 28.22 & 25.75 & 23.15 & 20.61 & 18.29 & 16.24 & 14.45 & 12.88 \\
\hline Case 181-190 & $150^{\circ}$ & 31.84 & 29.84 & 27.18 & 24.09 & 20.87 & 17.84 & 15.19 & 13.09 & 11.56 & 10.43 \\
\hline Case 191-200 & $170^{\circ}$ & 31.84 & 29.58 & 26.61 & 23.14 & 19.69 & 16.47 & 13.50 & 11.03 & 9.42 & 8.71 \\
\hline
\end{tabular}




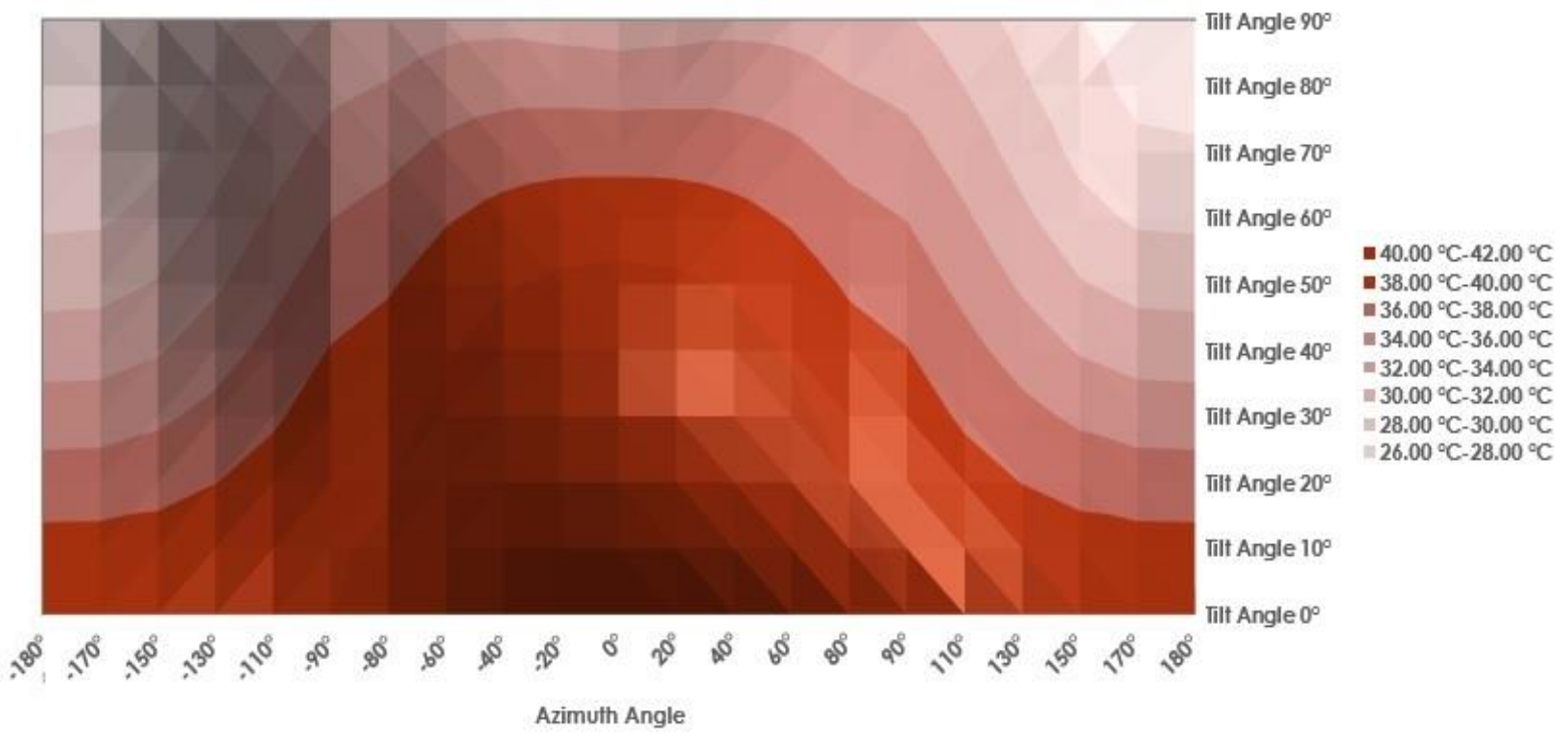

Fig. 13: Results of average module temperature $\mathrm{T}_{\text {Mod }}$ with different fixed tilt angles and different azimuth angles

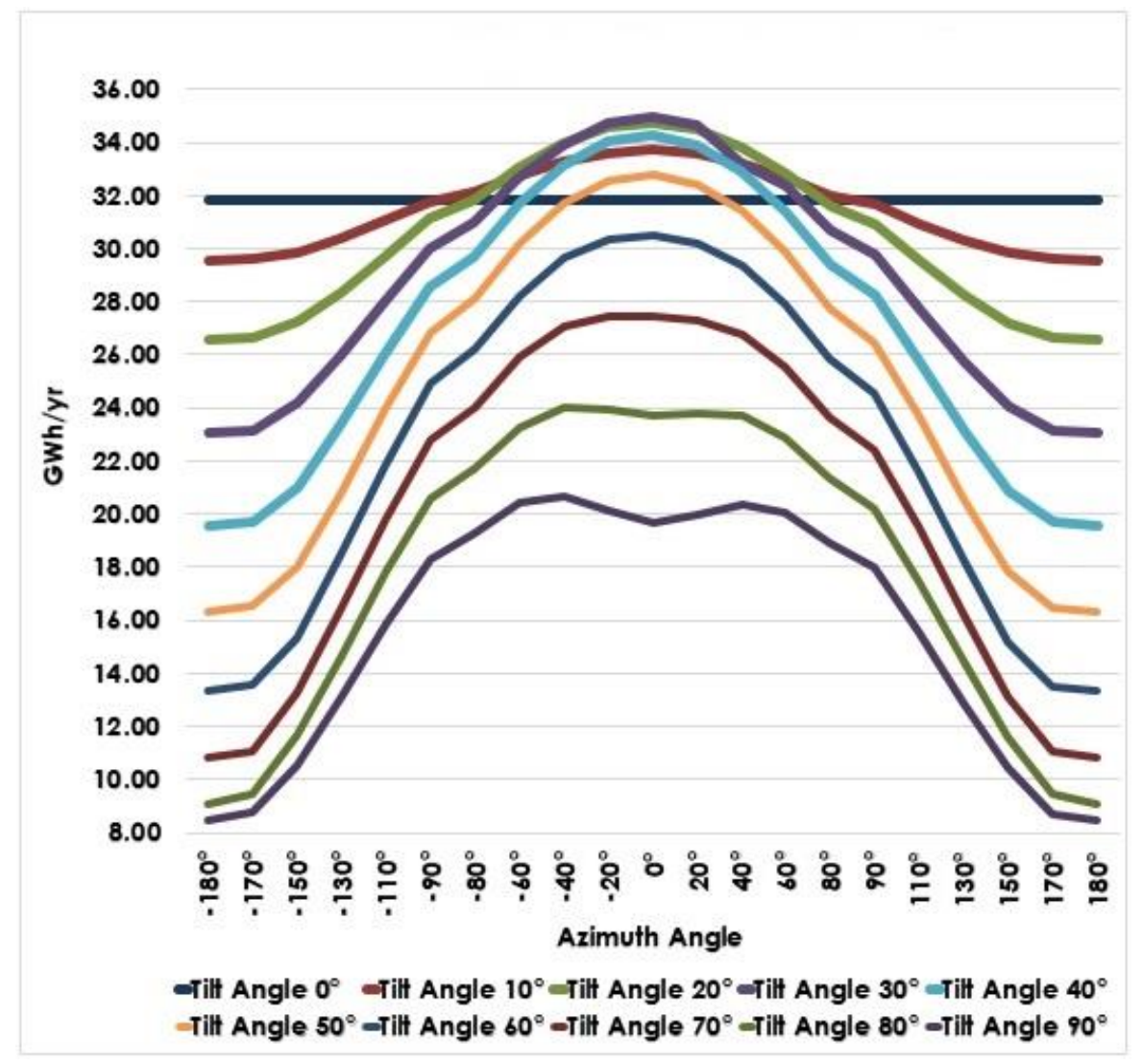

Fig. 14: Results of energy injected into Grid $\mathrm{E}_{\text {Grid }}$ with different fixed tilt angles and different azimuth angles 


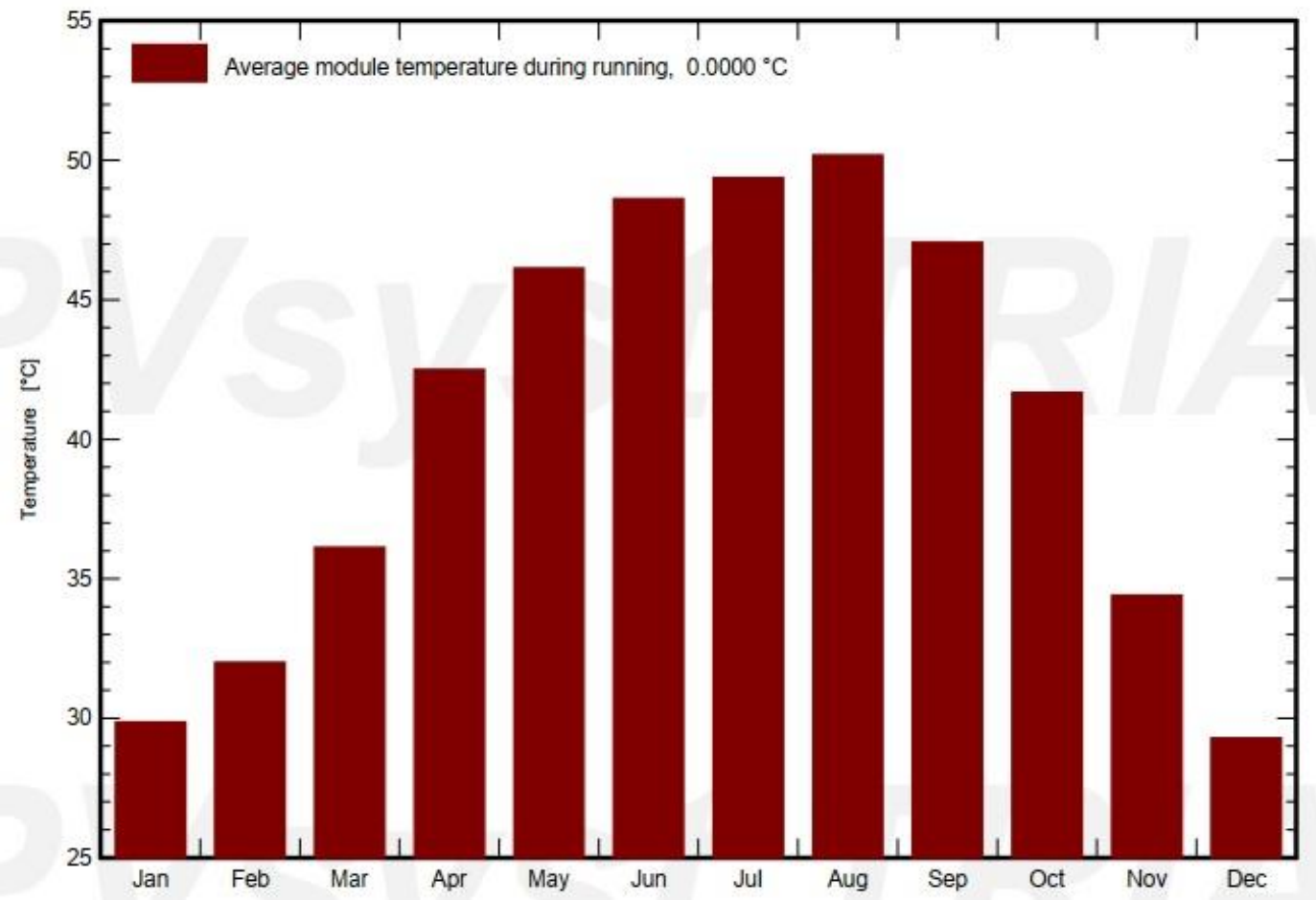

Fig. 15: PVsyst results of average module temperature $\mathrm{T}_{\text {Mod }}$ for Case 73 , tilt angle is $20^{\circ}$ and azimuth angle is $60^{\circ}$

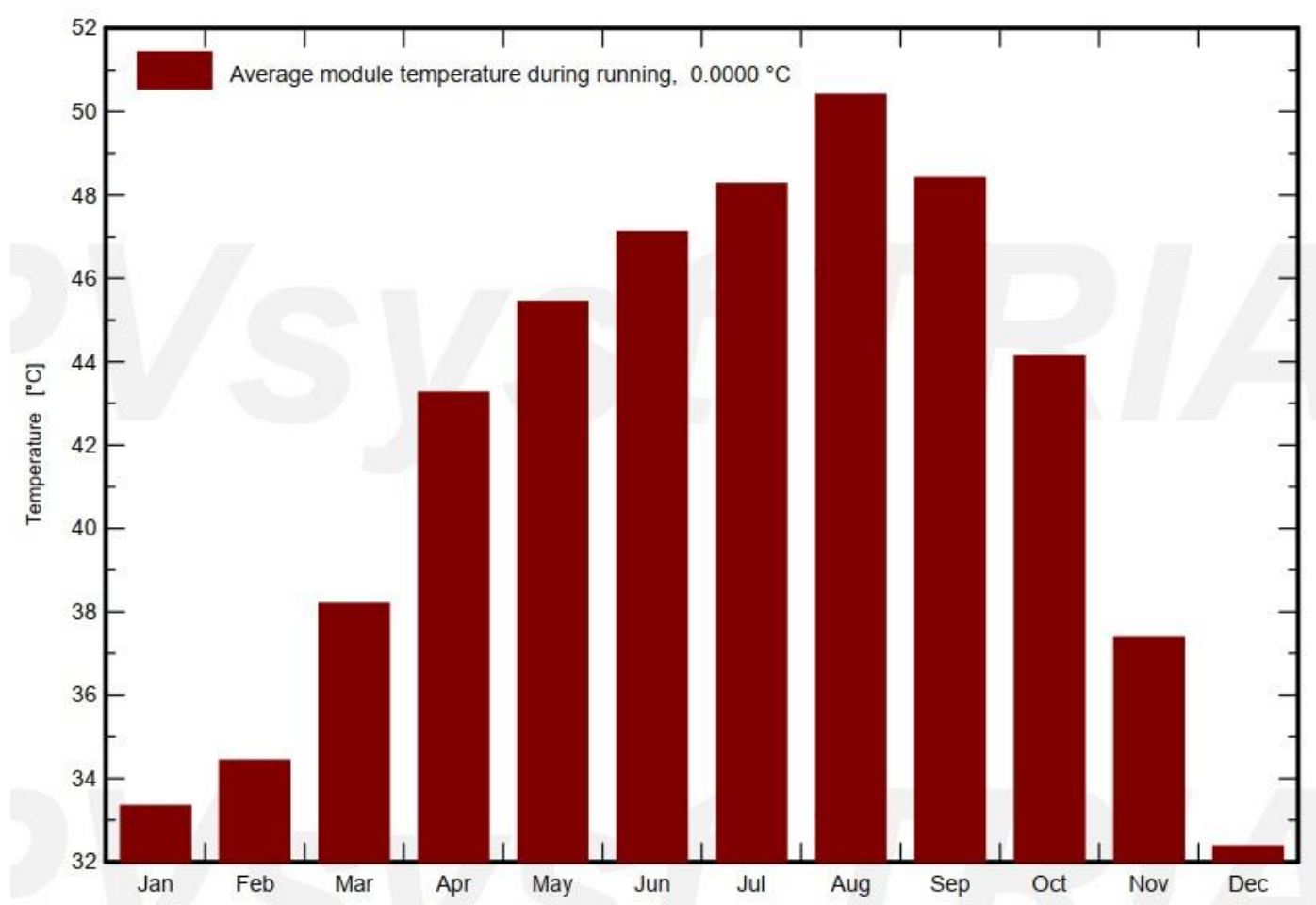

Fig. 16: PVsyst results of average module temperature $\mathrm{T}_{\text {Mod }}$ for Case 114 , tilt angle is $30^{\circ}$ and azimuth angle is $0^{\circ}$ 


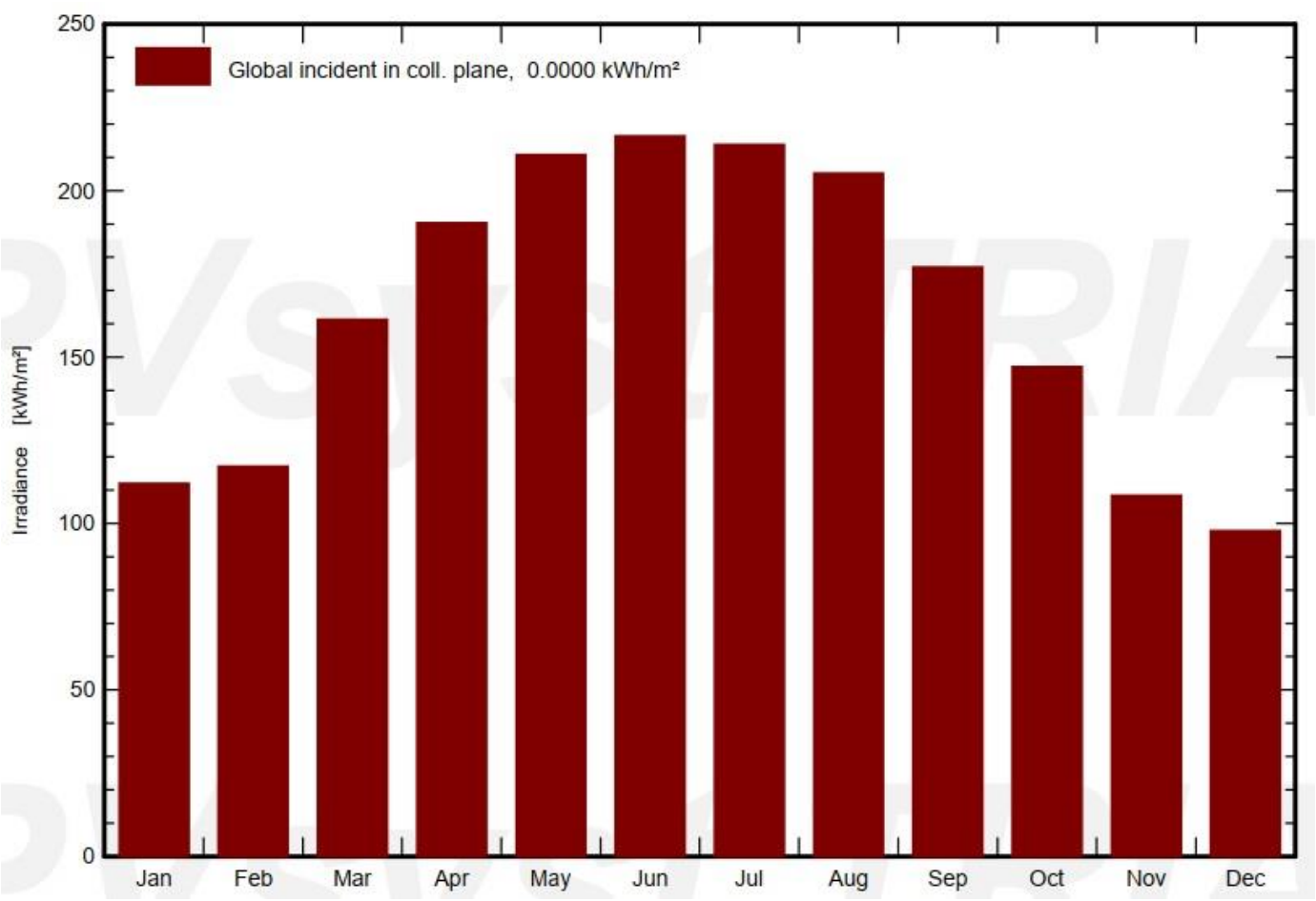

Fig. 17: PVsyst results of global incident in collector plane Glob $_{\text {Inc }}$ for Case 73 , tilt angle is $20^{\circ}$ and azimuth angle is $-60^{\circ}$

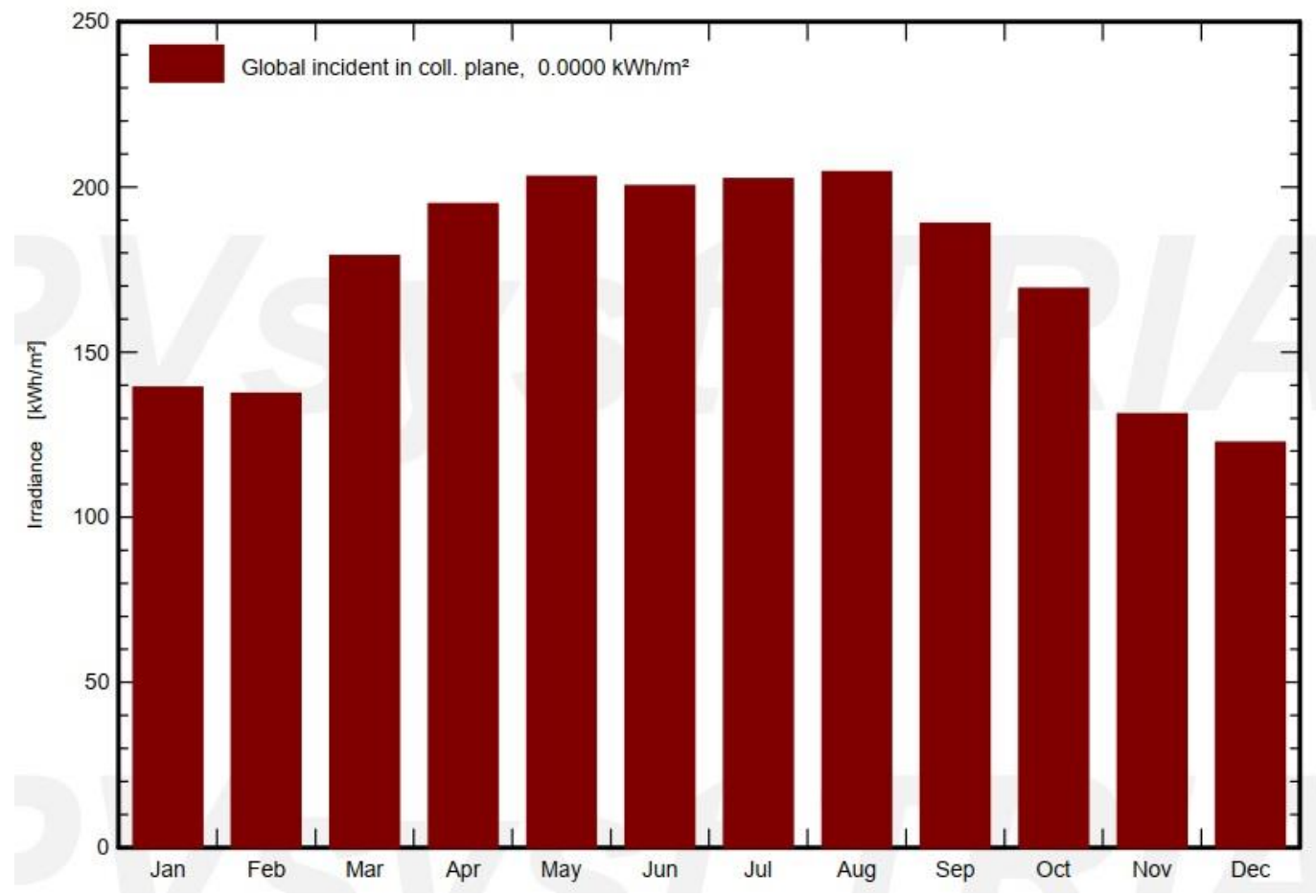

Fig. 18: PVsyst results of global incident in collector plane $\mathrm{Glob}_{\mathrm{Inc}}$ for Case 114, tilt angle is $30^{\circ}$ and azimuth 
angle is $0^{\circ}$

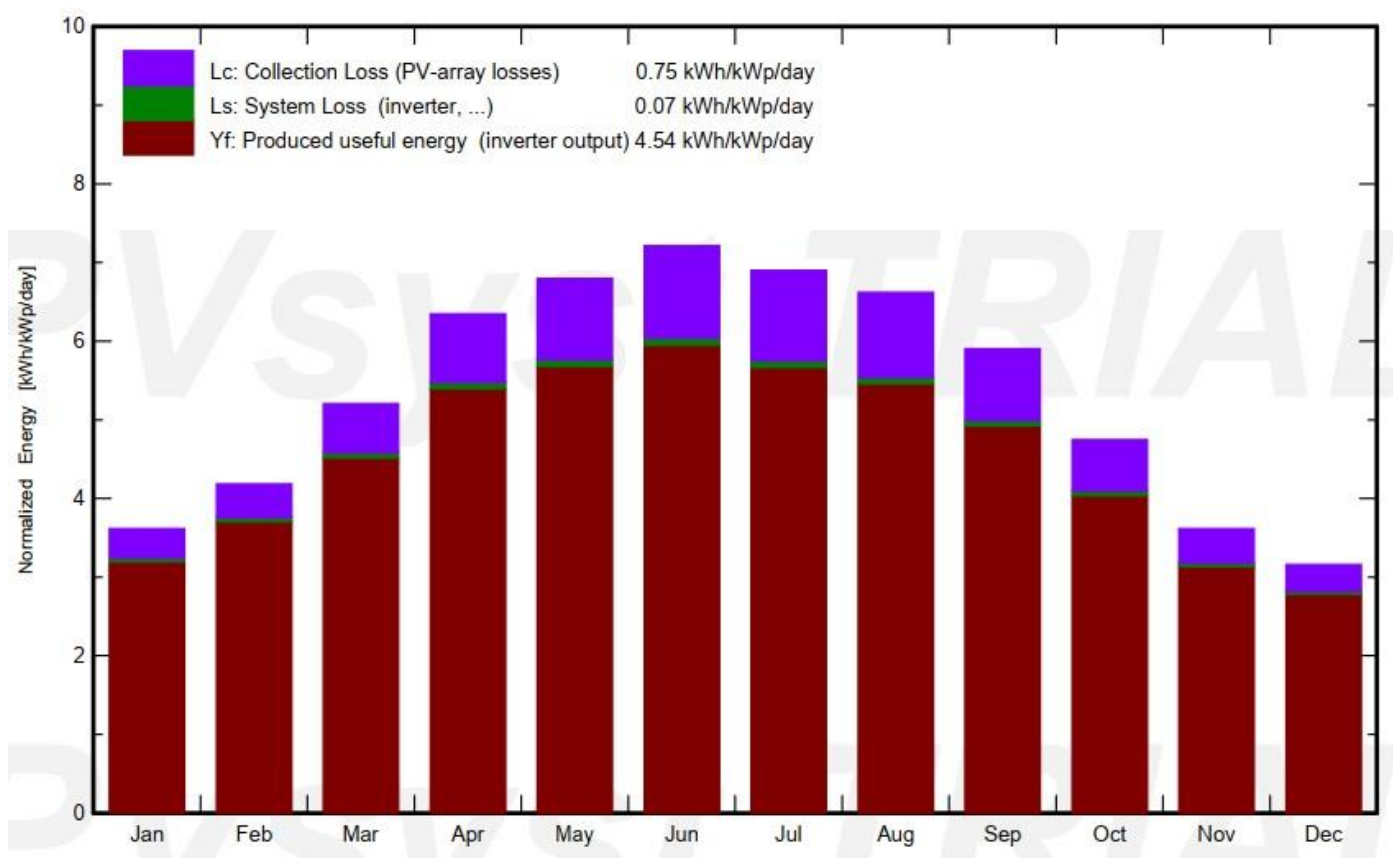

Fig. 19: PVsyst results of Normalized System Production $\mathrm{Y}_{\mathrm{f}}$ for Case 73 , tilt angle is $20^{\circ}$ and azimuth angle is $60^{\circ}$

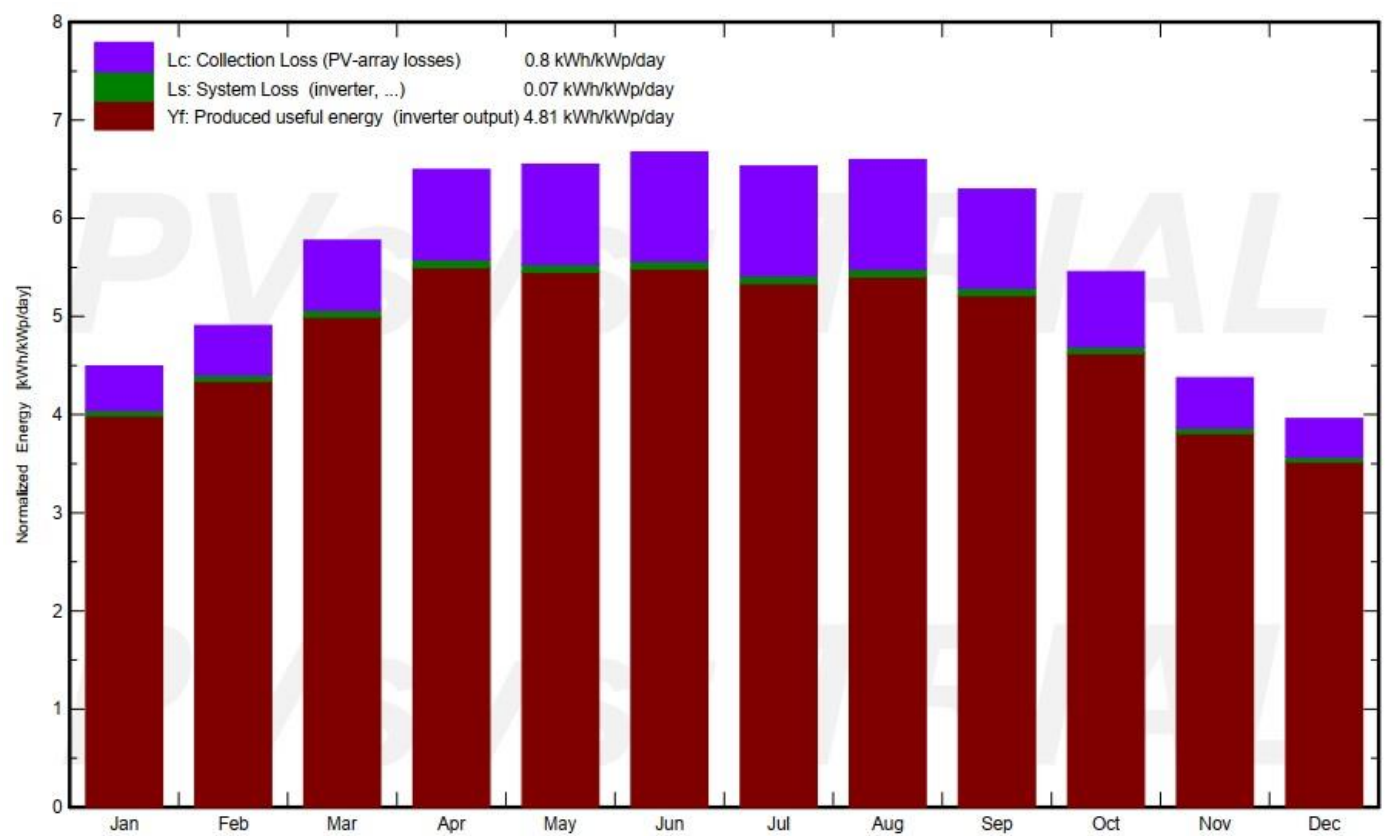

Fig. 20: PVsyst results of Normalized System Production $\mathrm{Y}_{\mathrm{f}}$ for Case 114 , tilt angle is $30^{\circ}$ and azimuth angle is $0^{\circ}$ 


\title{
Loss diagram
}

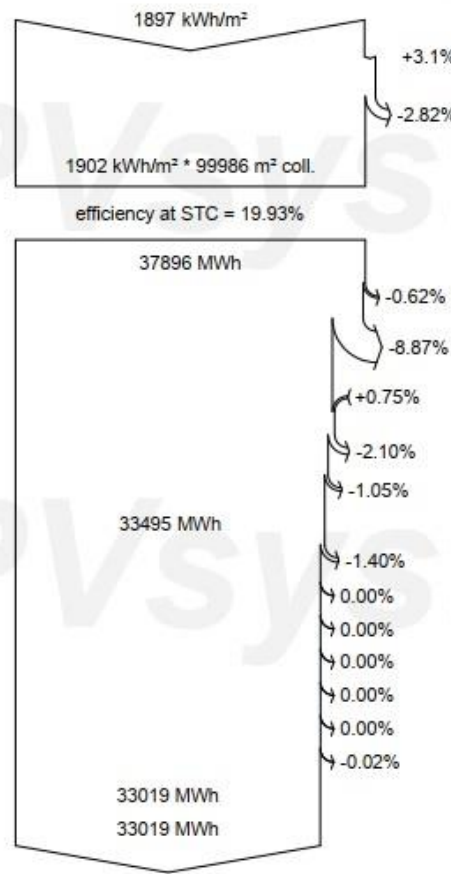

\author{
Global horizontal irradiation \\ Global incident in coll. plane \\ IAM factor on global \\ Effective irradiation on collectors \\ PV conversion \\ Array nominal energy (at STC effic.) \\ PV loss due to irradiance level \\ PV loss due to temperature \\ Module quality loss \\ Mismatch loss, modules and strings \\ Ohmic wiring loss \\ Array virtual energy at MPP \\ Inverter Loss during operation (efficiency) \\ Inverter Loss over nominal inv. power \\ Inverter Loss due to max. input current \\ Inverter Loss over nominal inv. voltage \\ Inverter Loss due to power threshold \\ Inverter Loss due to voltage threshold \\ Night consumption \\ Available Energy at Inverter Output \\ Energy injected into grid
}

Fig. 21: PVsyst results of loss diagram for Case 73 , tilt angle is $20^{\circ}$ and azimuth angle is $-60^{\circ}$

\section{Loss diagram}

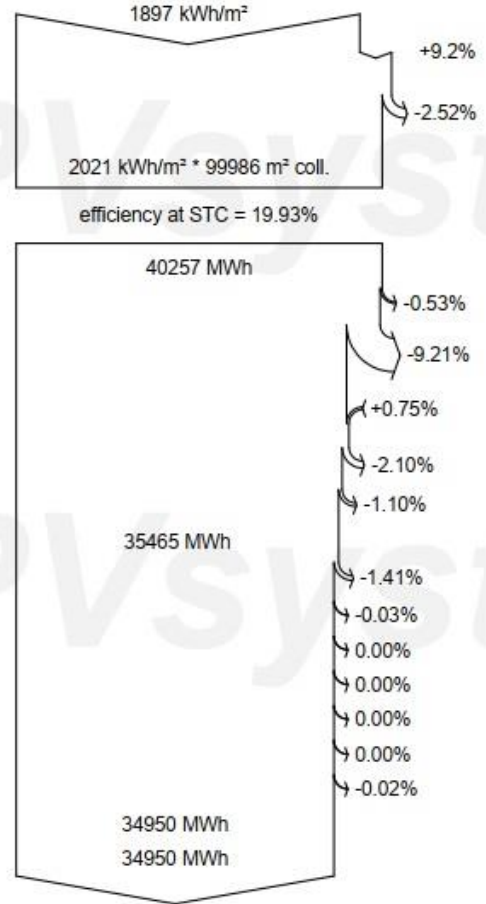

Global horizontal irradiation

Global incident in coll. plane

IAM factor on global

Effective irradiation on collectors

PV conversion

Array nominal energy (at STC effic.)

PV loss due to irradiance level

PV loss due to temperature

Module quality loss

Mismatch loss, modules and strings

Ohmic wiring loss

Array virtual energy at MPP

Inverter Loss during operation (efficiency)

Inverter Loss over nominal inv. power

Inverter Loss due to max. input current

Inverter Loss over nominal inv. voltage

Inverter Loss due to power threshold

Inverter Loss due to voltage threshold

Night consumption

Available Energy at Inverter Output

Energy injected into grid

Fig. 22: PVsyst results of loss diagram for Case 114, tilt angle is $30^{\circ}$ and azimuth angle is $0^{\circ}$ 
Table 4. Results of average module temperature $\mathrm{T}_{\mathrm{Mod}}$ for a selection of two seasonal dual tilt angles and different azimuth angles

\begin{tabular}{|c|c|c|c|}
\hline \multirow[t]{2}{*}{ Case No. } & \multirow[t]{2}{*}{ Azimuth Angle } & $\begin{array}{c}\text { Summer Tilt Angle: } \mathbf{1 0}^{\circ} \\
\text { Winter Tilt Angle: } \mathbf{5 0}^{\circ}\end{array}$ & $\begin{array}{r}\text { Summer Tilt Angle: } \mathbf{2 0}^{\circ} \\
\text { Winter Tilt Angle: } \mathbf{4 0}^{\circ}\end{array}$ \\
\hline & & \multicolumn{2}{|c|}{${ }^{\circ} \mathrm{C}$} \\
\hline Case 201-202 & $-80^{\circ}$ & 39.67 & 39.70 \\
\hline Case 203-204 & $-40^{\circ}$ & 41.67 & 41.64 \\
\hline Case 205-206 & $-20^{\circ}$ & 42.34 & 42.23 \\
\hline Case 207-208 & $\mathbf{0}^{\circ}$ & 42.59 & 42.44 \\
\hline Case 209-210 & $20^{\circ}$ & 42.32 & 42.22 \\
\hline Case 211-212 & $40^{\circ}$ & 41.65 & 41.61 \\
\hline Case 213-214 & $80^{\circ}$ & 39.66 & 39.69 \\
\hline
\end{tabular}

Table 5. Results of energy injected into Grid $\mathrm{E}_{\mathrm{Grid}}$ for a selection of two seasonal dual tilt angles and different azimuth angles

\begin{tabular}{|c|c|c|c|}
\hline \multirow[t]{2}{*}{ Case No. } & \multirow[t]{2}{*}{ Azimuth Angle } & $\begin{array}{l}\text { Summer Tilt Angle: } \mathbf{1 0}^{\circ} \\
\text { Winter Tilt Angle: } \mathbf{5 0}^{\circ}\end{array}$ & $\begin{array}{l}\text { Summer Tilt Angle: } \mathbf{2 0}^{\circ} \\
\text { Winter Tilt Angle: } \mathbf{4 0}^{\circ}\end{array}$ \\
\hline & & \multicolumn{2}{|c|}{$\mathbf{G W h} / \mathbf{y r}$} \\
\hline Case 201-202 & $-80^{\circ}$ & 31.27 & 31.35 \\
\hline Case 203-204 & $-40^{\circ}$ & 34.77 & 34.72 \\
\hline Case 205-206 & $-20^{\circ}$ & 35.92 & 35.72 \\
\hline Case 207-208 & $\mathbf{0}^{\circ}$ & 36.33 & 36.07 \\
\hline Case 209-210 & $20^{\circ}$ & 35.84 & 35.63 \\
\hline Case 211-212 & $40^{\circ}$ & 34.62 & 34.53 \\
\hline Case 213-214 & $80^{\circ}$ & 31.08 & 31.12 \\
\hline
\end{tabular}

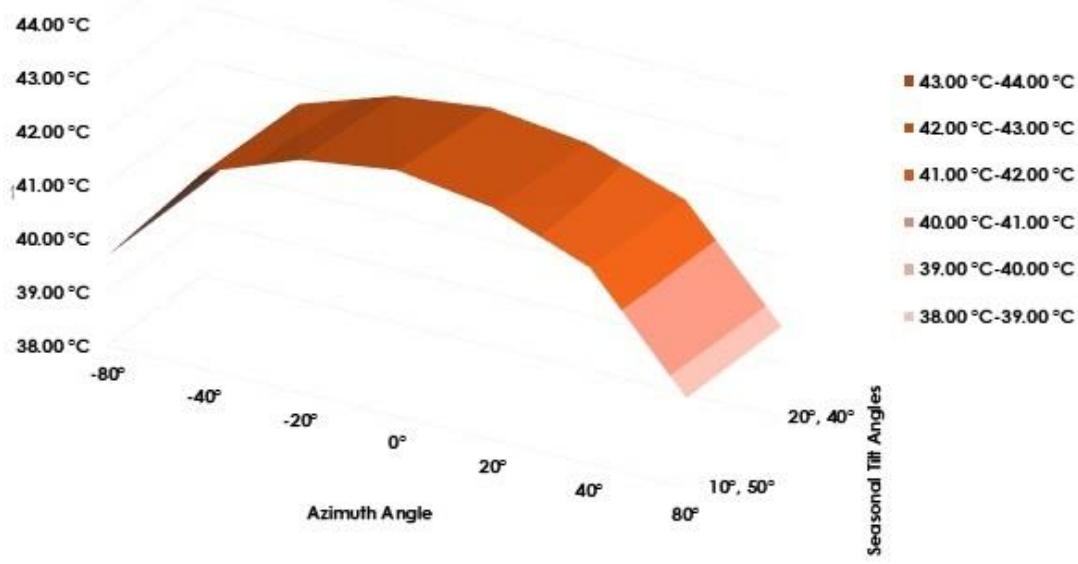

Fig. 23: Results of average module temperature $\mathrm{T}_{\text {Mod }}$ for a selection of two seasonal dual tilt angles and different azimuth angles 


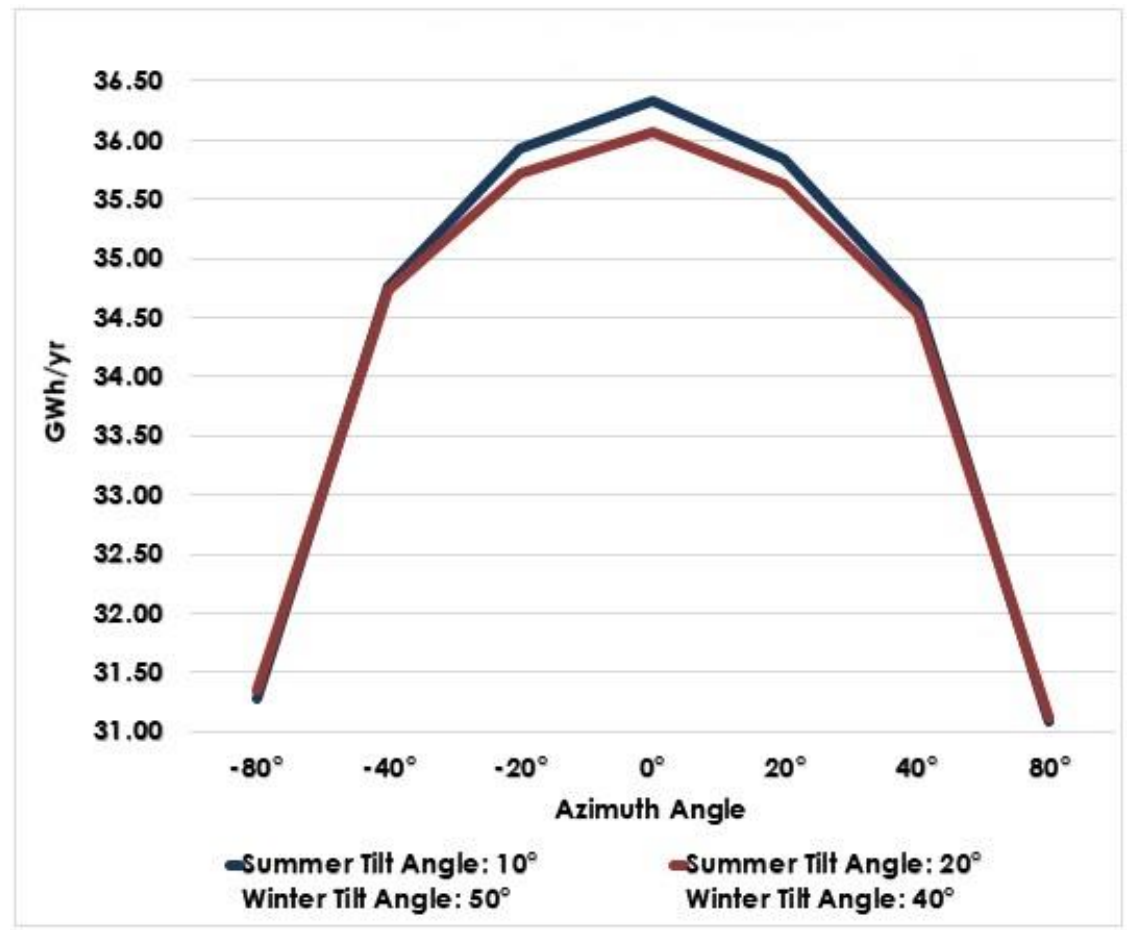

Fig. 24: Results of energy injected into Grid $E_{\text {Grid }}$ for a selection of two seasonal dual tilt angles and different azimuth angles

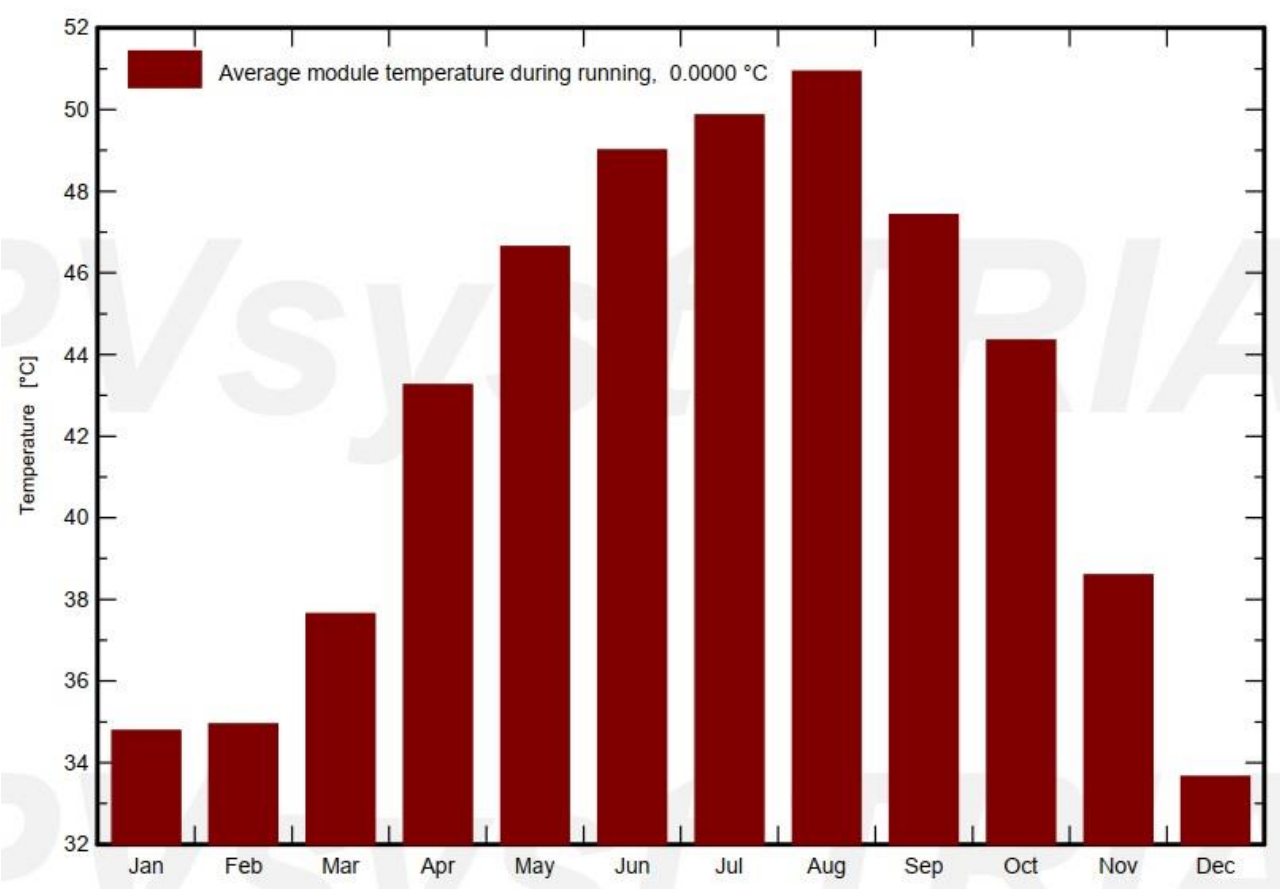

Fig. 25: PVsyst results of average module temperature $T_{\text {Mod }}$ for Case 207, summer tilt angle is $10^{\circ}$, winter tilt angle is $50^{\circ}$ and azimuth angle is $0^{\circ}$ 


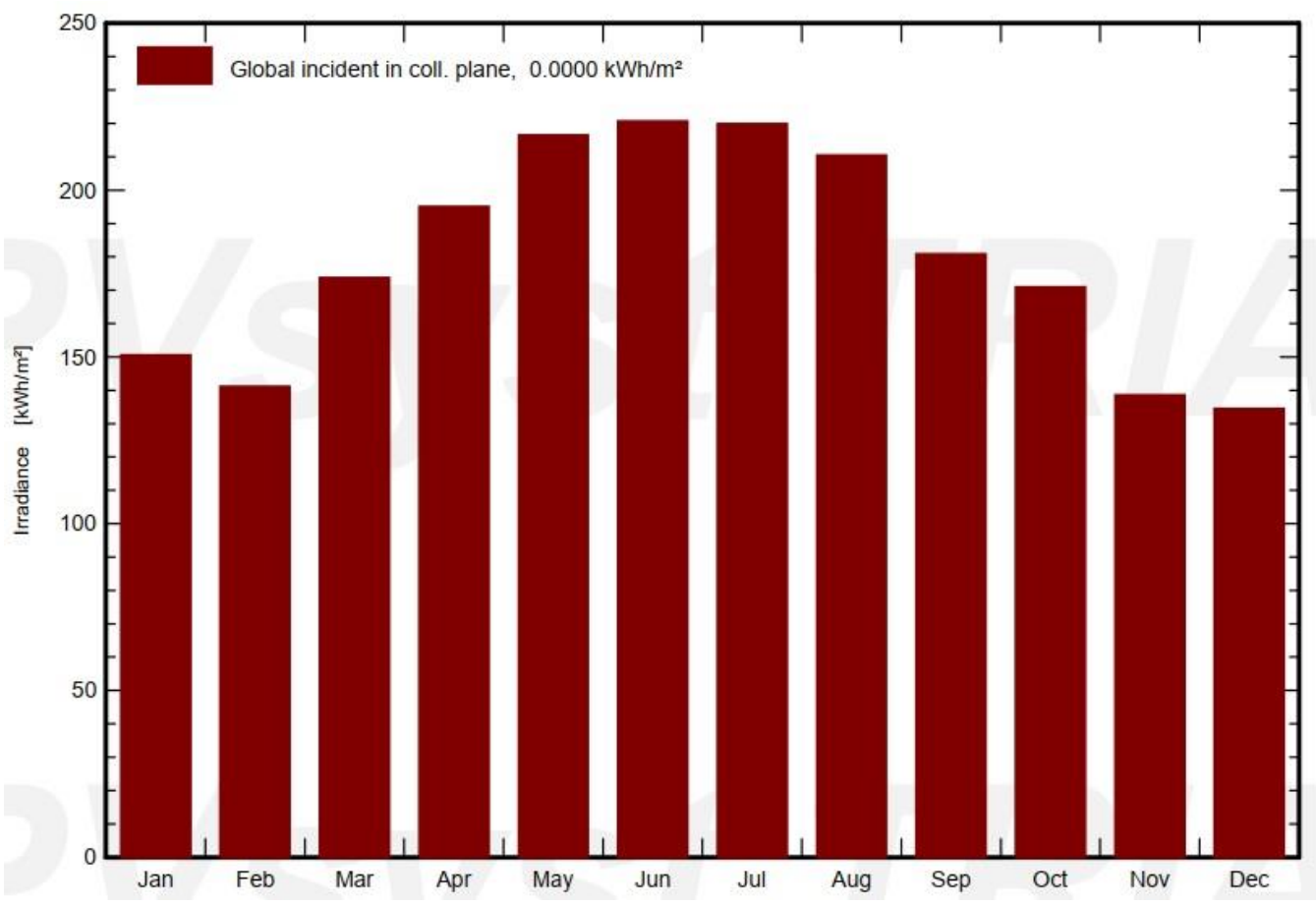

Fig. 26: PVsyst results of global incident in collector plane $\mathrm{Glob}_{\mathrm{Inc}}$ for Case 207 , summer tilt angle is $10^{\circ}$, winter tilt angle is $50^{\circ}$ and azimuth angle is $0^{\circ}$

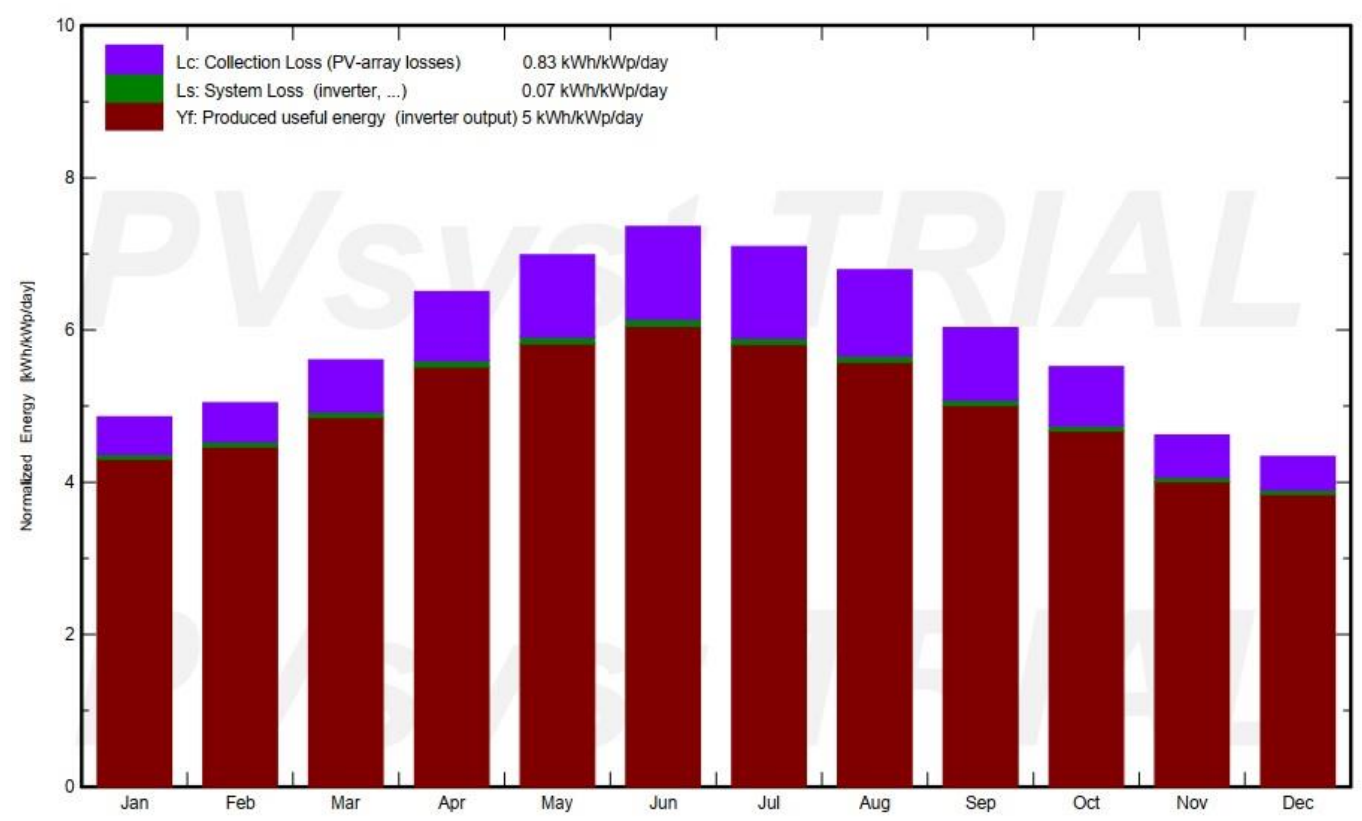

Fig. 27: PVsyst results of Normalized System Production $\mathrm{Y}_{\mathrm{f}}$ for Case 207, summer tilt angle is $10^{\circ}$, winter tilt angle is $50^{\circ}$ and azimuth angle is $0^{\circ}$ 


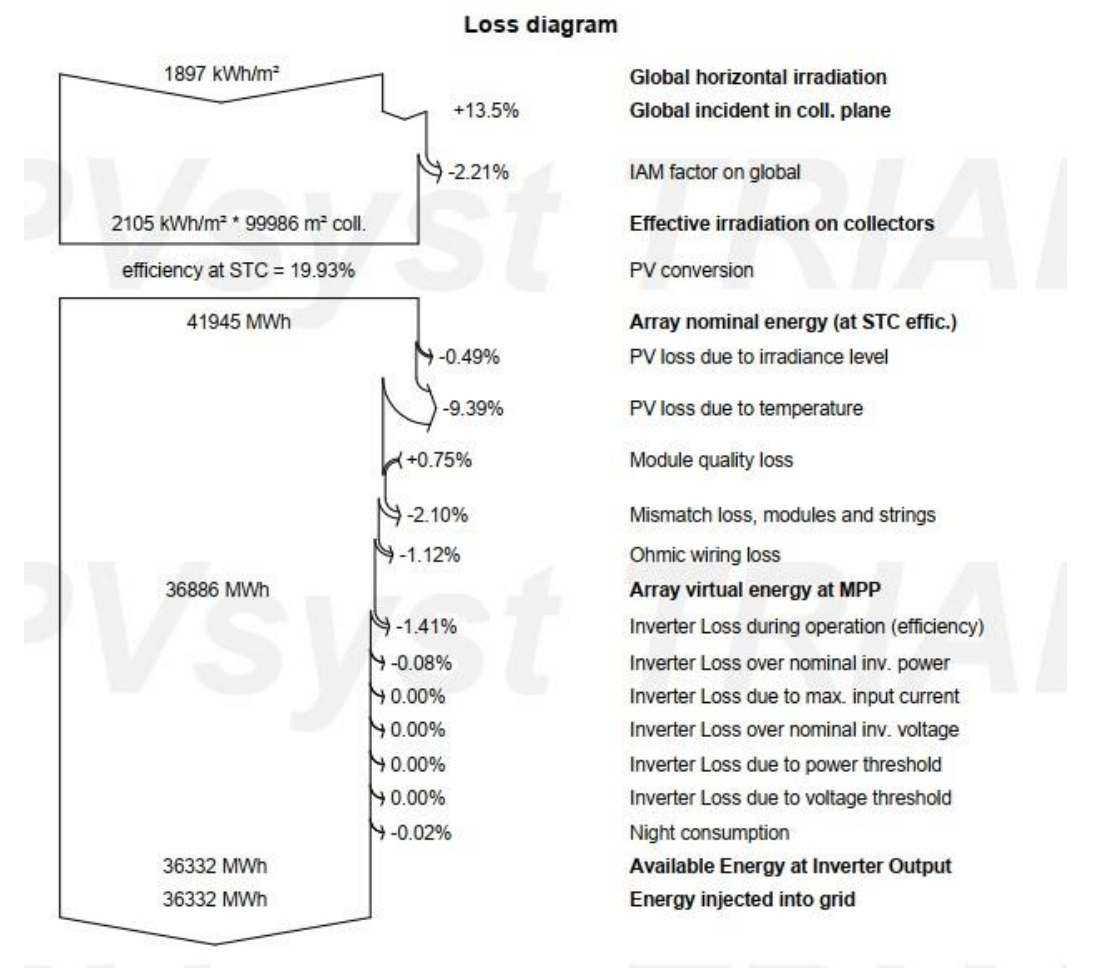

Fig. 28: PVsyst results of loss diagram for Case 207, summer tilt angle is $10^{\circ}$, winter tilt angle is $50^{\circ}$ and azimuth angle is $0^{\circ}$

\section{Conclusions}

At Cairo International Airport, the optimal yearly fixed tilt angle is $30^{\circ}$ when the azimuth angle is $0^{\circ}$, or when the PV panel is directed to the south. The optimal seasonal dual tilt angles are $10^{\circ}$ in summer and $50^{\circ}$ in winter when the azimuth angle is $0^{\circ}$.

Seasonal dual tilt angles are highly recommended, which increases power generation.

When moving from south towards north, the better results are limited to a $40^{\circ}$ direction east or west. When moving from south towards north, less power generation is obtained. Using $90^{\circ}$ tilt angle is the worst angle and not preferred.

The main challenge in the OrientationOptimization study to increase the values of "Average module temperature" and "Global Incident in collector plane", which leads to an increase in the "Energy injected into grid".

It is possible to generate around $36.5 \mathrm{GWh}$ per year by installing a PV Plant and using an optimal PV panel orientation. Also, it will be possible to save about $50 \%$ of the annual electricity consumption of Cairo International Airport Terminal Building 3.

\section{References}

[1] R . Kumar, C.S. Rajoria, A. Sharma and S. Suhag, "Design and simulation of standalone solar PV system using PVsyst Software: A case study", Materials Today: Proceedings, pp. $1-7,2020$

[2] N. Rehman, M. Uzair and U Allauddin, "An optical-energy model for optimizing the geometrical layout of solar photovoltaic arrays in a constrained field", Renewable Energy Vol. 149, pp. 55-65, 2020.

[3] K. Kuo et al., "Comprehensive assessment of the long-term energy harvest capabilities for PV systems with different tilt angles: Case study in Taiwan", Renewable and Sustainable Energy Reviews Vol. 97, pp. 74-89, 2018.

[4] P. Ocłon et al., "Modeling and experimental validation and thermal performance assessment of a sun-tracked and cooled PVT system under low solar irradiation", Energy Conversion and Management Vol. 222, pp. 1-23, 2020.

[5] M. Mansoor, S. Simon, K. A. Kumar, K. Sundareswaran, P. S. R. Nayak and N. P. Padhy, "Impact and economic assessment on solar PV mirroring system - A feasibility report", Energy Conversion and Management, pp. 1-17, 2019.

[6] N. Salimzadeh, F. Vahdatikhaki and A. Hammad, "Parametric modeling and surface-specific sensitivity analysis of PV module layout on building skin using BIM", Energy \& Buildings Vol. 216, pp. 1-14, 2020.

[7] O. A. Al-Shahri et al., "Solar photovoltaic energy optimization methods, challenges and issues: A comprehensive review", Journal of Cleaner Production Vol. 284, pp. 1-18, 2021. 
[8] S. Sukumaran and K. Sudhakar, "Fully solar powered Raja Bhoj International Airport: A feasibility study", ResourceEfficient Technologies Vol. 3, pp. 309-316, 2017.

[9] S. Sreenath, K. Sudhakar and A. F. Yusop, "Airport-based photovoltaic applications", Progress in Photovoltaics, pp. 1$21,2020$.

[10] R. Ruther and P. Braun, "Solar airports: A future multibillion Euro PV market?", Solar Airports Vol. 6, pp. 30-34, 2005.

[11] J. L. Wybo, "Large-scale photovoltaic systems in airports areas: safety concerns", Renewable and Sustainable Energy Reviews Vo. 21, pp. 402-410, 2013.

[12] I. Araki, M. Tatsunokuchi, H. Nakahara and T. Tomita, "Bifacial PV system in Aichi Airport-site Demonstrative Research Plant for New Energy Power Generation", Solar Energy Materials \& Solar Cells Vol. 93, pp. 911-916, 2009.

[13] A. B. Othman, K. Belkilani and M. Besbes, "Global solar radiation on tilted surfaces in Tunisia: Measurement, estimation and gained energy assessments", Energy Reports Vol. 4, pp. 101-109, 2018.

[14] M. S. Emeara, A. F. AbdelGawad and A. H. El Abagy, "A Case Study of Cairo International Airport "CIA": Proposed Installation of Photovoltaic "PV" for High EnergyProduction", International Journal of Mechanical and Production Vol. 10, pp. 399-410, 2020.

[15] B. Meng, R.C.G.M. Loonen and J.L.M. Hensen, "Data-driven inference of unknown tilt and azimuth of distributed PV systems", Solar Energy Vol. 211, pp. 413-432, 2020.

[16] M. K. Sharma, D. Kumar, S. Dhundhara, D. Gaur and Y. P. Verma, "Optimal Tilt Angle Determination for PV Panels Using Real Time Data Acquisition", Global Challenges, pp. 1-12, 2020.

[17] C. Yu, YY. S. Khoo, J. Chai, S. Han and J. Yao, "Optimal Orientation and Tilt Angle for Maximizing in-Plane Solar Irradiation for PV Applications in Japan", Sustainability, pp. $1-8,2019$.

[18] S. Yadav, S.K. Panda and C. Hachem-Vermette, "Optimum azimuth and inclination angle of BIPV panel owing to different factors influencing the shadow of adjacent building", Renewable Energy Vol. 162, pp. 381-396, 2020.

[19] Optimum Solar Panel Angle: A Guide, https://www.13kuga.com.au/solar-panel-orientation-vsproduction/. Last seen on December 2020.

[20] Sun Path, https://solarschoolhouse.org/. Last seen on December 2020.

[21] S. Sundaram, and C. J. S. Babu, "Performance evaluation and validation of $5 \mathrm{MWp}$ grid connected solar photovoltaic plant in South India", Energy Conversion and Management Vol. 100, pp. 429-439, 2015.

[22] V. Sharma, S.S. Chandel, "Performance analysis of a 190 $\mathrm{kWp}$ grid interactive solar photovoltaic power plant in India", Energy Vol. 55, pp. 476-485, 2013.

[23] H. Vidal, M. Rivera, P. Wheeler and N. Vicencio, "The Analysis Performance of a Grid-Connected $8.2 \mathrm{kWp}$ Photovoltaic System in the Patagonia Region", sustainability Vol. 12, pp. 1-16, 2020.

[24] PVsyst Help, https://www.PVsyst.com/help. Last seen on July 2020.

[25] S. A. Kalogirou, "Chapter two - Environmental Characteristics", Solar Energy Engineering, pp. 49-120, 2009.

[26] A. Dube, M. Rizwan, and M. Jamil, "New approach for maximizing generation and optimal utilization of available space for solar PV system", Journal of Renewable and Sustainable Energy Vol. 10, pp. 1-13, 2018.

[27] Cairo, Egypt - Sunrise, Sunset, and Daylength, https://www.timeanddate.com/sun/egypt/cairo. Last seen on February 2021. 